\title{
ROMA HUKUKUNDA PROFESYONEL ATLETLER İLE YAPILAN TÜKETIM ÖDÜNCÜ SÖZLEŞMELERİ d。
}

\author{
LOAN CONTRACTS WITH PROFESSIONAL ATHLETES IN ROMAN LAW
}

\author{
Ali Selkor ATAK* $m$
}

Makale Bilgi

Gönderilme: 10/10/2020 Kabul: 05/12/2020

Anahtar Kelimeler

Roma Hukuku, Tüketim Ödüncü Sözleşmesi

(Mutuum),

Profesyonel Atlet, Atletizm Yarışmaları (Agones-Certamina Athletarum),

Faiz.

\section{Article Info}

Received: 10/10/2020

Accepted: 05/12/2020

\section{Keywords}

Roman Law, Loan for Consumption (Mutuum),

Professional Athlete, Athletics (AgonesCertamina Athletarum), Interest.

\section{Özet}

Antik Çağ'da varlıklı bir aileye mensup olmayan profesyonel atletler, beslenme, antrenman ve yarışmalara katılmak için seyahat etme zorunluluğundan doğan giderleri karşılama olanağından yoksundular. Bu masrafları karşılayabilmek için tüketim ödüncü sözleşmeleri yaparak para ödünç almak zorunda kalmaktaydılar. Roma hukukunda profesyonel atletler ile yapılan tüketim ödüncü sözleşmeleri, olağan tüketim ödüncü sözleşmelerine nazaran farklı özellikler taşımaktaydı. Öncelikle bir profesyonel atlet katıldığ yarışmalardan zafer ve ödül kazanmadığ 1 sürece almış olduğu ödüncü ödemek zorunda değildi. Atletlerle yapılan tüketim ödüncü sözleşmelerinin olağan tüketim ödüncü sözleşmelerinden ayrıldığı diğer bir nokta faiz konusundaydı. Olağan bir tüketim ödüncü sözleşmesinde faiz talep edilebilmesi için bunun ödünç sözleşmesinden ayrı olarak stipulatio adı verilen sözlü şekle bağlı bir sözleşme ile ayrıca taahhüt edilmiş olması gerekiyordu. Atletler ile yapılan tüketim ödüncü sözleşmelerinde ise, şekle bağlı olmayan bir "pactum"un (anlaşmanın) yapılması, faiz talep edilebilmesi için yeterli görülüyordu ve stipulatio yapılması zorunluluğu aranmıyordu. Atletlerle yapılan tüketim ödüncü sözleşmeleri bu yönleriyle deniz ödüncü sözleşmelerine benzerlik göstermekteydi.

\begin{abstract}
In antiquity, professional athletes were unable to cover the expenses for nutrition, training and travelling to participate competitions, unless they belonged to a wealthy family. In order to cover these expenses, they had to borrow money by concluding loan contracts. In Roman law, loan contracts with professional athletes had different features compared to ordinary loan contracts. First of all, a professional athlete did not have to pay the loan he received, unless he won victories and awards from the competitions he participated in. Another point where loan contracts with professional athletes differed from the ordinary loans is interest. In order to be able to claim interest on an ordinary loan agreement, it was necessary to extract a promise from the borrower in the form of a separate verbal contract (stipulatio), besides the ordinary loan contract. On the other hand, regarding the loan contracts with professional athletes, there was no need to conclude a stipulatio in order to demand interest, rather it was sufficient to conclude a formless pactum (agreement). Loan contracts with athletes resemble maritime loans in these aspects.
\end{abstract}




\section{GİRIŞ}

İnceleme konumuz olan Roma hukukunda profesyonel atletler ile yapılan tüketim ödüncü sözleşmeleri, antik Roma dünyası ile Yunan dünyasının kesiştiği pek çok alandan birini oluşturmaktadır. Yunan kültürel çevresi, Roma dünyasını önemli ölçüde etki altına almıştır ve Yunan atletizm yarışmalarının Roma dünyasındaki varlığı da bunun örneklerinden yalnızca biridir. Antik Yunan kültürel çevresinin zihniyeti, Roma hukukunun fikrî ve ekonomik temellerini de etkilemiştir. Bununla birlikte, antik Yunan hukukunun Roma hukuku üzerindeki etkisinin ise Yunan kültürünün farklı alanlardaki etkilerine göre daha sınırlı olduğu savunulmaktadır ${ }^{1}$. Yunan hukukunun Roma hukuku üzerindeki etkisinin kapsamı ile ilgili ayrıntılı tartışmalara değinmeksizin, bu etkinin görüldüğü hukukî işlemlerden birinin profesyonel atletlerle yapılan tüketim ödüncü sözleşmeleri olduğu ve bu hukukî işlemlerin antik Yunan etkisinin baskın olduğu hukukî ilişkiler arasında bulunduğu söylenebilir² .

Profesyonel atletler ile yapılan tüketim ödüncü sözleşmeleri, bazı noktalarda olağan tüketim ödüncü sözleşmelerinden farklılık göstermektedir. Roma hukukunda tüketim ödüncü sözleşmesi (mutuum) tek tarafa borç yükleyen bir sözleşme olarak kabul edilmekteydi ve verilen ödünç karş1lığında faiz elde etmek isteniyorsa bunun için taraflar arasında tüketim ödüncü sözleşmesinin yanı sıra sözlü şekle bağlı ayrı bir sözleşme (stipulatio) ${ }^{3}$ yapılması gerekirdi. Yani stipulatio yapılmadan tüketim ödüncü verilmiş olması durumunda ödünç verenin faiz talep etmesi mümkün değildi, yalnızca ödünç verilmiş miktarın iadesi talep edilebilirdi ${ }^{4}$. Aşağı 1 da ayrıntılı olarak inceleneceği gibi profesyonel atletlerle yapılan ödünç sözleşmelerinde ise faizin stipulatio yapılmaksızın şekle bağlı olmayan basit bir anlaşma (pactum) ile kararlaştırılabileceği, tartışmalı olmakla birlikte, genellikle kabul edilmektedir. Bu tür bir tüketim ödüncü sözleşmesini, olağan tüketim ödüncü sözleşmelerinden ayıran diğer bir özellik, ödünç alan profesyonel atletin ancak zafer ve ödül kazandığı takdirde geri ödeme yükümlülüğünün doğması ve katıldığ müsabakalarda bir ödül kazanamazsa ödüncü geri ödeme yükümlülüğünün bulunmamasıdır.

Çalışmamızda ilk olarak antik Yunan dünyasında atletizm ve atletler hakkında kısa açılamalara yer verme gereği doğmuştur. Bunun bir sebebi Yunan atletizm yarışmalarının ve atletlerin Roma dünyasındaki görünüş biçimlerinin daha anlaşılır olarak ortaya konabilmesini sağlamaya çalışmaktır. Diğer bir sebep ise atletizmin gelişiminde ve uygulamasında en önemli rolün antik Yunanlılara ait olmasıdır. Atletizmin antik Yunan'daki özelliklerinden bahsetmeksizin Roma'daki durumun anlaşılması çok kolay olmayacaktır. Bununla birlikte Yunan atletizminin doruk noktası olarak kabul edilen ${ }^{5}$ Olympia'da düzenlenmiş atletizm yarışmaları (Olimpiyat oyunları) $^{6}$ ise bu çalışmanın esas konusunu teşkil etmediği için derinlemesine incelenmeyecektir.

Roma'da profesyonel atletlerin neden ödünç ilişkilerine girme ihtiyacını duyduklarının daha iyi anlaşılabilmesi için öncelikle Roma dünyasında atletlerin nasıl bir konuma sahip olduğunun, ana hatlarıyla da olsa, ele alınması gerekmiştir. Bununla birlikte bu çalışmanın ana amacı antik Yunan ve Roma'da atletizm yarışmalarının özelliklerini ve profesyonel atletlerin durumlarını ayrıntılı olarak ortaya koymak değildir. Bu nedenle farklı yarışma türlerinin, atletizm dallarının ve dövüş müsabakalarının taşıdığı niteliklerden yalnızca kısaca bahsedilmiş ve Roma'da profesyonel atletlerin oluşturdukları meslekî birlikler çalışmanın kapsamı dışında tutulmuştur.

\footnotetext{
${ }^{1}$ KASER, Max: Das römische Privatrecht, das altrömische, das vorklassische und klassische Recht (RP I), erster Abschnitt, 2. Aufl., Verlag C. H. Beck, München, 1971, s.178-179; ancak bu etkinin dönemden döneme değişiklik göstermiş olduğu ve özellikle Roma imparatorluğunun son dönemlerinde artmaya başladığı göz ardı edilmemelidir, KASER, Max: Das römische Privatrecht, die nachklassischen Entwicklungen (RP II), zweiter Abschnitt, 2. Aufl., Verlag C. H. Beck, München, 1975, s.7.

${ }^{2}$ WACKE, Andreas: Athleten als Darlehensnehmer nach römischem Recht, Studia et Documenta Historiae et Iuris (SDHI), 44, 1978, s.440.

${ }^{3}$ Stipulatio: Eski hukuk döneminden beri, sözlü şekle tâbi, tek tarafa borç yükleyen, dar hukuk davaları doğuran ve Roma hukukunun borç doğurucu genel sözleşme tipi. Taraflardan birisinin belli kelimeler kullanarak sorduğu soruya, diğer tarafin aynı kelime ile kayıtsız ve şartsız olarak muvafakat cevabı vermesiyle oluşurdu, UMUR, Ziya: Roma Hukuku Lügatı (Lügat), Fakülteler Matbaası, İstanbul, 1983, s.202.

${ }^{4}$ RADO, Türkân: Roma Hukuku Dersleri, Borçlar Hukuku, İstanbul 2014, s.51 vd.

${ }^{5}$ YOUNG, David C.: A Brief History of the Olympic Games, Blackwell, Malden, 2004, s.12, s.137; KYLE, Donald G.: "Greek Athletic Competitions-The Ancient Olympics and More" (Olympics), in Christesen, Paul/Kyle, Donald G. (ed.), A Companion to Sport and Spectacle in Greek and Roman Antiquity, WILEY Blackwell, Malden, 2014, s.21.

${ }^{6}$ Crowther, Yunanlıların Olympia'da düzenlenen yarışmaları "Olimpiyat oyunları (Olympic Games)" değil "Olimpiyat yarışmaları (Olympic Contests [Agones])" olarak adlandırdıklarını belirtmektedir, CROWTHER, Nigel B.: Sport in Ancient Times (Sport), Praeger, Westport, 2007, s.56.
} 


\section{ANA HATLARIYLA ANTİK YUNAN'DA ATLETIZM YARISSMALARI}

Atletizm ve atletizm yarışmaları (özellikle Olympia'da düzenlenmiş olanlar [Olimpiyat oyunlar1]), antik Yunan tarihi boyunca Yunan kültür ve kimliğinde çok önemli bir yere sahipti ${ }^{7}$. Antik Yunan toplumunun bütün sinıflarından erkek vatandaşlar düzenli olarak atletizm ile uğraşmışlardı ${ }^{8}$ ve atletizm, Yunan vatandaşların eğitiminin önemli bir unsuruydu.

Günümüzde "beden gücünü, çevikliği, yetenekleri geliştirmeye yarayan koşu, atlama, ağırlık kaldırma, atma vb. tek başına yapılan bireysel sporların genel adı" ${ }^{\prime 10}$ anlamında kullanılan "atletizm" kelimesi Yunanca "athlos" (yarışma, müsabaka) ve "athlon" (ödül) ${ }^{11}$ kelimelerinden türetilmiştir ${ }^{12}$. Dilimizde atletizm ile uğraşan kimseler için kullanılan "atlet" "athletēs" kelimesinden gelmektedir ve "athletēs" = "yarışmacı", "bir agon'a (yarışmaya) katılan", "ödül için yarışan"14 anlamındadır15. "Agon" ise "mücadele, savaş", "dövüş/savaş alanı", "kalabalık" ve "toplantı, kurul" anlamlarını taşımasının yanı sıra esas olarak "yarışma" anlamına gelmekte idi ${ }^{16}$. Bugün atletizm yarışmaları olarak tanımladığımıza benzer müsabakalar ${ }^{17}$ için Antik Yunanlıların kullanmış oldukları tâbir gymnikos agon ${ }^{18}$ idi. Yunanca gymnos kelimesi çıplak anlamına gelmektedir ${ }^{19}$. Yunanlı atletler tamamen çıplak olarak antrenman yaparlar ve dinî festivallerde halk önünde çırılçıplak yarışırlard ${ }^{20}$. Gymnikos agon terimi de katılanların çıplak olarak mücadele ettikleri yarışmaları ifade etmekteydi ${ }^{21}$.

$\mathrm{Bu}$ oyunlardaki yarışma programı, oyunun düzenlenmiş olduğu dönem ve yerlere göre çeşitli farklılıklar göstermekle birlikte programda temel olarak pist (ve saha) müsabakaları $(\text { koupha })^{22}$ ve dövüş müsabakaları (barea athla) olarak gruplandırılabilecek yarışmalar yer alırdı. Birinci grupta yer alan yarışmalar, stadion, diaulos, dolichos ve askerî teçhizatla koşulan hoplitess veya hoplitodromos'tur ${ }^{23}$. Stadion ${ }^{24}$, günümüzdeki gibi oval olmayıp dikdörtgen şeklinde olan koşu pistinin baştan sona bir defa katedilmesi ile koşulan ve yaklaşık olarak ${ }^{25}$ bugünkü 200 metre

${ }^{7}$ KYLE, Donald G.: Sport \& Spectacle in the Ancient World (Sport), Second Edition, WILEY Blackwell, Malden, 2015, s.5; REMIJSEN, Sofie: The End of Greek Athletics in Late Antiquity, Cambridge University Press, Cambridge, 2015 , s.2

${ }^{8}$ CROWTHER, Sport, s.57; POTTER, David Stone: The Victor's Crown: A History of Ancient Sport from Homer to Byzantium, Oxford University Press, Oxford, 2012, s.110.

${ }^{9}$ TEKİN, Oğuz: Eski Yunan ve Roma Tarihine Giriş, İletişim Yayınları, İstanbul, 2008, s.166 vd.; POTTER, s.110 vd.

${ }^{10}$ Tanım için bkz. Türk Dil Kurumu Güncel Türkçe Sözlük, https://sozluk.gov.tr/?kelime=atletizm (Erişim tarihi: 08.09.2020).

${ }_{11}$ Atletizm yarıșmalarında sembolik de olsa maddi değeri de olsa daima bir ödül verilmesinin söz konusu olduğu ve paranın yanı sıra, zafer tacı, kalkan veya zeytinyağı ile dolu amphora'ların da ödül olarak verildiği belirtilmektedir, MILLER, Stephen G.: Ancient Greek Athletics, Yale University Press, New Haven and London, 2004, s.11.

${ }^{12}$ MILLER, s.11; KYLE, Olympics, s.21; GARDINER, Edward Norman: Athletics of the Ancient World, Ares Publishers, Inc., Chicago, 1983, s.1'de "athlete" kelimesinin, daha eski olan ve kelimenin kök anlamını teşkil eden "yarışma" anlamındaki "athlos" kelimesinden geldiği ileri sürülmektedir.

${ }^{13}$ Tanım için bkz. Türk Dil Kurumu Güncel Türkçe Sözlük, https://sozluk.gov.tr/?kelime=atlet (Erişim tarihi: 08.09.2020).

${ }^{14}$ YOUNG, s.3, s.93.

15 REISCH, Emil: "Athletai" (Athletai), RE II, 2 (Paulys Realencyclopädie der classischen Altertumswissenschaft), Alfred Druckenmüller Verlag, Stuttgart, 1896, s.2049.

16 REISCH, Emil: "Agones" (Agones), RE I, 1 (Paulys Realencyclopädie der classischen Altertumswissenschaft), Alfred Druckenmüller Verlag, Stuttgart 1893, s.836; GOLDEN, Mark: Sport in the Ancient World from A to Z, Routledge, London, 2004, s.5; MILLER, s.13; CROWTHER, Sport, s.57.

${ }^{17}$ Günümüzde atletizm yarışmaları kapsamında görülmeyen güreş, boks ve pankration gibi bazı müsabakalar antik Yunan ve Roma'da gymnikos agon kapsamı içinde yer almaktaydı.

${ }^{18}$ Önceleri Olympia'daki standart yarışma programında yer almasa bile pek çok yerdeki yarışma programlarının parçası olan binicilik yarışmaları hippikos agon, müzik yarışmaları ise mousikos agon olarak adlandırılmaktaydı, MILLER, s.13 vd.; diğer yarışma türleri ve agon ile ilgili yapılan farklı sinıflandırmalar için bkz. REISCH, Agones, s.836 vd.; GOLDEN, s.5; MILLER, s.129.

${ }^{19}$ GOLDEN, s.74 (“Gymnasium” başlı̆ğ); MILLER, s.11; TEKİN, s.166; "Çıplak olarak vücut terbiyesi yapmak” anlamına gelen jimnastik kelimesinin de gymnos'tan geldiği belirtilmektedir, AKURGAL, Ekrem: "Eski Yunanlılarda Spor”, Eski Çağda Ege ve İzmir, İzmir, 1993, s.75 [Makalenin ilk basimı: Ülkü Dergisi, (17), 1943].

${ }^{20}$ MILLER, s.11; CROWTHER, Sport, s.58; çıplak olarak antrenman yapıp yarışmak, Yunan kültürünün en önemli işaretlerinden olup Yunanlılara has olan ve onları (beyaz ve siska bedenleriyle alay konusu olabilen) Yunanlı olmayanlardan ayıran önemli bir özellikti, NEWBY, Zahra: Greek Athletics in the Roman World, Victory and Virtue, Oxford University Press, Oxford, 2005, s.1-2; MANN, Christian: "Greek Sport and Roman Identity", in Scanlon, Thomas F. (ed.), Sport in the Greek and Roman Worlds, Vol. 2: Greek athletic Identities and Roman Sports and Spectacle, Oxford University Press, Oxford, 2014, s.174; Yunanli atletlerin çılak olarak yarışmalarının kökenine ve olası nedenlerine dair çeşitli teoriler için bkz. MILLER, s.11 vd., s.233; CROWTHER, Sport, s.59; POTTER, s.77 vd.; KYLE, Sport, s.82 vd.

${ }^{21}$ Yunanlıların tarihi boyunca kamusal alanda çıplak olmanın hoş karşılanmadığı ve utanç verici bulunduğu, bunun tek istisnasının spor (atletizm yarışmaları ve antrenmanları) olduğu belirtilmektedir, KYLE, Sport, s.82 vd.

22 GOLDEN, s.96.

${ }^{23}$ MILLER, s.31 vd.; KYLE, Olympics, s.27; POTTER, s.74 vd.

${ }^{24}$ Stadion'un, 600 antik (Yunan) feet (ayak) ölçü birimi olan stade ile eşanlamlı olarak kullanıldığı gibi, aynı zamanda bu mesafedeki koşu yarışını ve bu yarışmaların (ve diğer atletizm yarışmalarının) yapıldığı alanı da ifade etmek için kullanılan bir terim olduğu belirtilmektedir, GOLDEN, s.157; PLEKET, Henry Willy: "The Olympic Games in antiquity” (Olympic Games), European Review, 12(3), 2004, s.403; ayrıca bkz. KYLE, Olympics, s.27; POTTER, s.40; doktrinde bu yarışmayı stade olarak nitelendiren yazarların olduğu da görülmektedir, YOUNG, s.25; NEWBY, s.178, s.216; CROWTHER, Sport, s.59, s.61, s.62, s.84.

25 Ölçü birimi yöreden yöreye farklılık gösterdiği için yarışmalarıdaki mesafelerin de yarışmanın yapıldığı yere göre değiştiği belirtilmektedir, örneğin Olympia'daki stadion 192,28 metre uzunluğundayken, Delphi'deki 177,5, Nemea'daki 178 metre uzunluğundadır, GOLDEN, s.158; KYLE, Olympics, s.27; ayrıca bkz. MILLER, s.33; POTTER, s.75. 
koşu yarışına (sprint) karşılık geldiği kabul edilen ${ }^{26}$ yarışmadır. Diaulos ${ }^{27}$, stadion' un bir gidiş ve bir de geliş olmak üzere iki kere katedilmesiyle koşulup başladığı yerde sona eren ${ }^{28}$ ve yaklaşık olarak bugünkü 400 metre yarışına karşılık geldiği kabul edilen ${ }^{29}$ koşu yarışıdır. Dolichos, dayanıklılığın ön planda olduğu bir uzun mesafe koşu yarışı olarak nitelendirilebilir ${ }^{30}$. Hoplites ise yarışanların miğfer giyip, ellerinde kalkan ve bazen de bronz baldır zırhı veya tekmelik ile koştukları yarışmadır ${ }^{31}$. Pist (ve saha) yarışmalarından olduğu kabul edilebilecek ${ }^{32}$ diğer bir müsabaka türü ise pentathlon idi. Pentathlon, beş ayrı spor dalını içeren bir yarışmaydı: disk atma (discos), uzun atlama (halma), cirit atma (akōn veya akontion), koşu (stadion) ve güreş (palē $)^{33}$. Bunlardan koşu ve güreş için pentathlon'dan bağımsız ayrı müsabakalar da düzenlendiği halde, disk atma, uzun atlama ve cirit atma müsabakalarına yalnızca pentathlon' un bir parçası olarak yer verilirdi ve bu dallar için pentathlon dışında yarışılması söz konusu değildi ${ }^{34}$.

Dövüş müsabakaları, güreş (palē), boks (pyx, pygmachia veya pygme) ve pankration idi ${ }^{35}$. Bu müsabakalar için Yunanlıların kullanmış oldukları tâbir, "ağır dallar/müsabakalar" anlamına gelen barea athla idii ${ }^{36}$. Antik çağdaki dövüs müsabakalarında sıklet farkı gözetilmemekteydi ${ }^{37}$, bu nedenle de daha ağır olan dövüşçüler daha avantajlı konumdayd1 ${ }^{38}$. Bu müsabakalarda sıklet fark1 gözetilmediği gibi bir zaman veya raunt sınırlaması da söz konusu değildi3 ${ }^{39}$.

Güreşte, galip gelmek isteyen güreşçinin rakibini üç defa yere düşürmesi gerekiyordu ${ }^{40}$. Boksta ve pankration'da da mücadele, dövüşçülerden birisi nakavt olana veya pes edene kadar devam ederdi ${ }^{41}$, çünkü puanlama sistemi kullanılmıyordu ve bir dövüşçünün puanla kazanması mümkün değildi ${ }^{42}$. Antik Yunan boksu (pygme, pyx, pyxmachio) ve pankration'da taraflar öylesine sert dövüşürlerdi ki, dövüşlerin ciddi yaralanmalarla hatta bazen dövüşçülerden birinin ölümüyle bile sonuçlandığı görülürdü ${ }^{43}$. Antik çağdaki atletlerin çoğu, modern olimpiyatların

\footnotetext{
${ }^{26}$ MILLER, s.31; PLEKET, Olympic Games, s.401; YOUNG, s.25.

${ }^{27}$ Diaulos'ın kelime olarak karşıllı̆̆ııı bazı İngilizce kaynaklarda "çifte kaval (double pipe)" (GOLDEN, s.51), bazılarında ise "çifte flüt (double flute)" (KYLE, Olympics, s.27) şeklinde verildiği görülmektedir. Bu kavramın modern dillere ne şekilde çevrilmesi gerektiği ile ilgili tartışmalar ve Türkçede "aulos" için en uygun karșllığın "zurna" (dolayısıyla "diaulos" için de "çifte zurna") olabileceği hakkında bkz. APAYDIN İSABABAYEVA, Ayna: "Antik Edebî ve Felsefi Kaynaklarda Aulos ve Syrin ve Tercüme Problemleri”, Sosyal Bilimler Dergisi (SOBIDER), 2(2), 2015, s.53 vd., s.70.

${ }^{28}$ YOUNG, s.175; POTTER, s.74.

${ }^{29}$ MILLER, s.32; YOUNG, s.20, s.27.

${ }^{30}$ Dolichos'ta koşulan mesafenin tam olarak ne kadar olduğu hakkında bir görüs birliği yoktur. Koșu pistinde 7 tur (yaklaşık 1.345 metre) ile 20 veya 24 tur (yaklaşık 3.845 veya 4.600 metre) arasında değiş̧en mesafenin katedilmesiyle tamamlanan bir yarış olduğunu savunan farklı görüşler vardır, GOLDEN, s.55; PLEKET, Olympic Games, s.403; POTTER, s.75; MILLER, s.32 (yazar koşulması gereken tur sayısını 20 veya 24 tur olarak verdikten sonra mesafeyi 7,5 ile $9 \mathrm{~km}$. şeklinde belirtmiştir); Young, dolichos'ta koşulan mesafe ile ilgili olarak en fazla benimsenen görüşün bu müsabakada 20 tur yani yaklaşı 3.845 metre koşulduğu yönünde olduğunu belirtmektedir, YOUNG, s.26; aynı yönde KYLE, Olympics, s.27.

${ }^{31} \mathrm{Bu}$ yarışmada da koşulan mesafe yarışın düzenlendiği yerden yere değiş̧mekle birlikte, Olympia'da diaulos ile aynı mesafe (yaklaşık 400 metre) katedilmekteydi, GOLDEN, s.84; MILLER, s.32; YOUNG, s.28; KYLE, Olympics, s.27.

${ }^{32}$ LEE, Hugh M.: "Greek Sports in Rome", in Christesen, Paul/Kyle, Donald G. (ed.), A Companion to Sport and Spectacle in Greek and Roman Antiquity, WILEY Blackwell, Malden, 2014, s.535; PLEKET, Henry Willy: "Inscriptions as Evidence in Greek Sport" (Inscriptions), in Christesen, Paul/Kyle, Donald G. (ed.), A Companion to Sport and Spectacle in Greek and Roman Antiquity, WILEY Blackwell, Malden, 2014, s.106; antik çağ yazarlarından Philostratos'un disk atmayı güreş ile birlikte pentathlon'daki "ağır dallar/müsabakalar" altında sınıflandırdığı belirtilmektedir, GOLDEN, s.77.

${ }^{33}$ Pentathlon'un kökeninin, yarıșmada kazananın nasıl belirlendiğinin ve bu müsabakaların hangi sıra ile gerçekleştirildiğinin tam olarak bilinmediği belirtilmektedir, MILLER, s.60, s.73 vd.; CROWTHER, Sport, s.62; KYLE, Olympics, s.27; YOUNG, s.32 vd.

${ }^{34}$ MILLER, s.60; KYLE, Olympics, s.27.

${ }^{35}$ PLEKET, Olympic Games, s.403; KYLE, Olympics, s.29.

${ }^{36}$ KYLE, Olympics, s.29; bazı modern kaynaklarda genellikle dövüş müsabakaları için Yunanlıların kullandığı terime karşılık gelecek sekilde şekilde "heavy events" ("ağır dallar/müsabakalar") teriminin kullanıldığı görülmektedir, CROWTHER, Nigel B.: "Greek Games in Republican Rome" (Greek Games), L'antiquité classique, 52, 1983, s.269, s.271; GOLDEN, s.77, s.96; CROWTHER, Sport, s.67, s.75, s.93, s.172; PRITCHARD, David M.: "Sport, War and Democracy in Classical Athens", The International Journal of the History of Sport, 26(2), 2009, s.216, s.225 (DOI: 10.1080/09523360802513272), (http://dx.doi.org/10.1080/09523360802513272) (Erişim tarihi: 08.09.2020); POTTER, s.82, s.371; KYLE, Olympics, s.29; LEE, s.535, s.538; Newby, "heavy athletics" terimini kullanmıștır, NEWBY, s.163, s.196, s.199; bunun yanı sıra koşu müsabakaları ve pentatlonu içerecek şekilde "light events" ("hafif dallar/müsabakalar”) teriminin kullanıldığı kaynaklar için bkz. PLEKET, Olympic Games, s.403; LEE, s.535; PLEKET, Inscriptions, s.106.

${ }^{37}$ CRAIG, Steve: Sports and Games of the Ancients, Greenwood Publishing Group, Westport, 2002, s.82.

${ }^{38}$ Yunanlıların dövüş sporları için "ağır dallar/müsabakalar" terimini kullanmasının da müsabakalarda sıklet farkı gözetilmemesi nedeniyle daha ağır sporcuların daha avantajlı bulunmalarından veya bu dalların daha zorlu olduğunun kabul edilmesinden kaynaklanmış olabileceği belirtilmektedir, CRAIG, s.82; GOLDEN, s.77.

${ }^{39}$ MILLER, s.55; YOUNG, s.40; PLEKET, Olympic Games, s.404.

${ }^{40}$ Güreşçilerden birinin sırtının, omzunun veya yüzünün yere değecek şekilde düşmesi galibiyet için yeterliydi, rakibin iki omzunun da aynı anda yere değerek tuşa getirilmesi şart değildi, GOLDEN, s.175; MILLER, s.46; karş. CROWTHER, Sport, s.68.

${ }^{41}$ CORNELL, Tim J.: "On War and Games in the Ancient World", in Barney, Robert Knight/Martyn, Scott G./Wamsley, Kevin B. (ed.), Sixth International Symposium for Olympic Research, University of Western Ontario, London, Ontario, 2002, s.31; PRITCHARD, s.225.

${ }^{42}$ POTTER, s.82.

${ }^{43}$ PLEKET, Henry Willy: “Zur Soziologie des antiken Sports" (Soziologie), Mededelingen van het Nederlands Instituut te Rome, 36, 1974, s.72 (http://resources.huygens.knaw.nl/retroboeken/knir/\#page=71\&accessor=toc1\&source=36\&view=pdfPane) (Erişim tarihi: 08.09.2020); MILLER, s.56-57, s.59; YOUNG, s.41; POTTER, s.86 vd.
} 
barışç1l ve teselli edici sloganı "katılmak kazanmaktan daha önemlidir" yerine "zafer veya ölüm" ilkesi doğrultusunda hareket etmeyi tercih etmişlerdir ${ }^{44}$.

\section{ANTIK ROMA DÜNYASINDA PROFESYONEL ATLETLERIN TOPLUMSAL VE HUKUKÎ STATÜSÜ}

Çalışma konumuzu oluşturan "profesyonel atlet"ler, atletizmi hayatlarının hatırı sayılır bir safhasında esaslı bir tutku ve meslek olarak benimsemiş ve uygulamış olan ve kendilerini atlet veya yarışmacı olarak nitelendiren kimselerdir. Yani yerel veya bölgesel yarışmalarda yalnızca bir veya iki kere yarışmış amatör atletler bu kapsamda değerlendirilmemiştir ${ }^{45}$. Antik Yunan ve Roma'da, yukarıda belirtilmiş olan ölçütlere uymak kaydıyla, güreşçiler, boksörler ve pankration yapanlar da profesyonel atlet olarak kabul edilmişlerdir.

Antik Roma'da profesyonel atletlerin sosyo-ekonomik durumları ve toplumun hangi sosyal tabakasına mensup oldukları ile ilgili farklı görüssler vardır. Bazı yazarlar profesyonel atletlerin, toplum önünde gösteri sergileyen aktörler ve gladyatörler gibi, toplumun alt sosyal tabakasına mensup olduklarını savunmaktadırlar ${ }^{46}$. Farklı görüşte olan yazarlar ise İlk İmparatorluk (Principatus) Döneminde ve öncesinde oyunlara katılan atletlerden, bazıları toplumun daha alt kesimlerine mensup olsalar da, başarılı olmuş pek çoğunun seçkin ailelerden geldiklerini veya kazandıkları başarılarla elit statüsüne yükseldiklerini ve sosyo-ekonomik durumlarının ortalamanın üzerinde olduğunu belirtmektedirler ${ }^{47}$. Bu görüşü savunanlardan Remijsen, profesyonel atletlerin sonraki dönemlerde (geç antik çağda) homojen bir grup olmadıklarını ileri sürmekte ve atletler arasında bir ayrım yapmaktadır. Remijsen'e göre atletizmi meslek edinen bazı atletler, atletizm gösterileri sergilemeyip yalnızca periyodik olarak düzenlenen üst düzey atletizm yarışmalarına katılmaktadırlar. Remijsen bu atletleri "kariyer atletleri" (career athletes) olarak adlandırmaktadır. $\mathrm{Bu}$ atletler genellikle toplumun üst tabakasından varlıklı ailelere mensupturlar ${ }^{48}$. Diğer kategorideki atletler ise atletizm yarışmalarına katılma olanağı bulamayıp üst sınıftan Romalıların verdikleri ziyafetlerde düzenlenen eğlencelerde ücret karş1lı̆̆1 atletizm gösterileri sergilemektedirler. Bunlar gerekli maddî olanaklardan veya yeteneklerden yoksun olmaları nedeniyle üst düzey oyunlara katılamadıkları için ücret karşılığında çalışmak zorunda olan, atletizmi bir geçim kapısı olarak gören ve daha çok toplumun alt tabakasına mensup kimselerdir. Remijsen bu atletleri "atletizm gösterisi sunanlar" (athletic performers) olarak adlandırmışıır ${ }^{49}$. M.S. 2. ve 3. yüzyıllarda bu iki grup arasında geçişkenlik vardı ve birbirini dışlayan konumda değillerdi. Çünkü o dönemde çok sayıda küçük çaplı yerel oyun düzenlenmekteydi. Bu oyunlar alt seviyedeki atletlere daha büyük turnuvalara katılma olanağ sağlamaktaydı. Bu durum M.S. 4. yüzyılın başlarına kadar devam etmiştir. M.S. 4. yüzyılın ortalarından itibaren ise bu iki grup eskiden olduğu gibi daha içiçe değil birbirinden ayrışmış görünmektedir ${ }^{50}$. Beslenme, antrenman ve yarışmalara katılabilmek amacıyla yapılacak seyahat masrafları için para ödünç almaya ihtiyaç duyan atletler, üst düzey oyunlara katılmak isteyip bu oyunlarda yarışabilecek yeteneğe sahip olmakla birlikte gerekli maddî olanaklardan yoksun olan atletlerdir. Başka bir ifadeyle, Remijsen'in yaptığı ayrıma göre ele alınacak olursa, çalışma konumuz kapsamında kalan atletler üst düzey atletizm yarışmalarına katılmak istemekle birlikte üst sınıfa mensup olmayan ailelerden gelen, yetenekli olup yeterli maddi olanağı olmayan "kariyer atleti" adaylarıdır. Bu ayrıma değinmemizin sebebi "kariyer atletleri"nin hukukî statüsünün, ücret karşılığ1 atletizm gösterilerine çıkıp zenginleri eğlendirmek için kendilerini sergileyenlerinkinden farklı olduğunun düşünülmesidir. Büyük yarışmalara katılan "kariyer atletleri”nin aksine geç antik çağda ücret karşılığı atletizm gösterileri sergileyenlerin (athletic performers), şerefsizlikle (infamia) ${ }^{51}$ damgalanan aktörler ${ }^{52}$ ve gladyatörlerle hem yan yana

\footnotetext{
${ }^{44}$ WACKE, s.446; PLEKET, Olympic Games, s.409; ancak karş. CROWTHER, Nigel B.: "Second-Place Finishes and Lower in Greek Athletics" (Athletics), Zeitschrift für Papyrologie und Epigraphik, Bd. 90, 1992, s.97.

${ }^{45}$ REMIJSEN, s.220.

${ }^{46}$ WACKE, s.443; CORNELL, s.35; MANN, s.177.

${ }^{47}$ NEWBY, s.9 vd.; REMIJSEN, s.221; PLEKET, Soziologie, s.66, s.69, s.77, s.78.

${ }^{48}$ REMIJSEN, s.223, s.224.

${ }^{49}$ REMIJSEN, s.224 vd.

${ }^{50}$ REMIJSEN, s.224 vd.

${ }^{51}$ Infamia: Kelime olarak kötü şöhret, şerefsizlik. Infamia, bir kimsenin toplum içinde itibarını kaybetmesi idi, UMUR, Lügat, s.86; infamia konusunda ayrıntılı bilgi için bkz. GREENIDGE, A.H.J.: Infamia, Its Place in Roman Public and Private Law, Clarendon Press, Oxford, 1894, s.18 vd.; KASER, Max: "Infamia und ignominia in den römischen Rechtsquellen." (Infamia), Zeitschrift der Savigny-Stiftung für Rechtsgeschichte, romanistische Abteilung, 73, 1956, s.220 vd.; TÜRKOĞLU ÖZDEMIR, Gökçe: Roma Hukukunda Infamia (Şerefsizlik), Seçkin Yayınları, Ankara, 2008, s.17 vd.

${ }^{52}$ D.3.2.1 (Iulianus 1 ad ed.): "Praetoris verba dicunt: " infamia notatur... qui artis ludicrae pronuntiandive causa in scaenam prodierit: qui lenocinium fecerit:....” : "Praetor'un sözleri şöyledir: "Aşağıda belirtilenler infamia' ya uğrarlar:...rol ya da konuşma yapmak için sahneye çıkan kimse, genelev işleten kimse.....", metnin çevirisi için bkz. TÜRKOĞLU ÖZDEMIR, s.142.
} 
çalıştıkları hem de tıpkı sahneye çıkan aktörler ve arenada dövüşen gladyatörler gibi şerefsiz (infamis) $^{53}$ ilân edildikleri ileri sürülmektedir ${ }^{54}$. Aktörlerin ve gladyatörlerin (gladiatores) yanı sıra, vahşi hayvanlarla dövüşenler (bestiarii) ve gladyatör eğiticileri (lanistae), muhabbet tellâlları (lenones-genelev işletenler), fahişeler (meretrices) de şerefsizlikle (infamia) damgalanırlard $1^{55}$. $\mathrm{Bu}$ kimseler siyaset ile ilgilenemez, senatus üyeliği veya diğer önemli kamu hizmetlerini ifa edemezlerdi ${ }^{56}$. Bunun yanı sıra hâkimlik yapamazlar, tanık olarak dinlenemezler ve mahkemede başkalarını temsil edemezlerdii ${ }^{57}$. Ayrıca sahne sanatçıları ve gladyatörlerin eyalet kanunları gereğince, eyalet senatus'larında yer almaktan mahrum bırakıldıkları görülmektedir ${ }^{58}$.

Yarışmalara (agones veya certamina [athletarum]) $)^{59}$ katılan profesyonel atletler (Remijsen'in sınıflandırmasına göre "kariyer atletleri") ise, yukarıda verilen örneklerin aksine, esas amaçları yetenek ve cesaretlerini sergilemek olduğu için, utanç verici şerefsizlik (infamia) damgasıyla lekelenmemişlerdir ${ }^{60}$. Çünkü Roma hukukçularına göre atletler, para kazanma amacıyla sahneye çıkanlardan farklı olarak, yarışmalara yiğitlik ve hünerlerini sergileyip, bu sayede şöhret kazanmak amacıyla katılırlardı ${ }^{61}$ :

D.3.2.4.pr. (Ulp. 6 ad ed.)

"Athletas autem sabinus et cassius responderunt omnino artem ludicram non facere: virtutis enim gratia hoc facere. et generaliter ita omnes opinantur et utile videtur, ut neque thymelici neque xystici neque agitatores nec qui aquam equis spargunt ceteraque eorum ministeria, qui certaminibus sacris deserviunt, ignominiosi habeantur."

"Sabinus ve Cassius'un cevaplarında belirttikleri üzere atletlerin faaliyetleri kesinlikle sahne sanatçılarınınki gibi değildir, zira onlar (atletler) yeteneklerini (cesaretlerini, yiğitliklerinikahramanlıklarını-virtutis) sergilemeye çalışırlar. (Ve) Genellikle herkes tarafından kabul edildiği ve uygun görüldüğg̈ gibi, ne müzisyenler (müzik yarışmalarına katılanlar) ne atletler ne atlı savaş arabası yarışçıları ne atlara su verenler (veya yarışlardan sonra atlarla ilgilenenler) ${ }^{62}$ ve ne de kutsal oyunlarda hizmet edenler diğer faaliyetleri nedeniyle "şerefsiz" sayılırlar."

Romalı hukukçuların bu yaklaşımının sonraki dönemlerde İmparator Diocletianus ve Maximianus tarafından M.S. 3. yüzyılın sonlarında çıkartılmış ${ }^{64}$ ve atletlere çeşitli imtiyazlar tanıyan bir emirnamede de devam ettirildiği görülmektedir ${ }^{65}$ :

\section{C.10.54.1}

"Athletis ita demum, si per omnem aetatem certasse, coronis quoque non minus tribus certaminis sacri, in quibus vel semel romae seu antiquae graetiae, merito coronati non aemulis corruptis ac redemptis probentur, civilium munerum tribui solet vacatio."

\footnotetext{
${ }^{53}$ Infamis: Şerefsizliğe (infamia) çarpılmış kimse; fena şöhretli kişi. Bu kişiler magistra seçilemezler, davada başkalarını temsil edemezler; magistra, kendi takdirine göre, başkalarından istemediği teminatı onlardan isteyebilir, şahitliklerini dinlemeyebilirdi. Toplumda itibar görmezlerdi, UMUR, Lügat, s.86.

${ }^{54}$ REMIJSEN, s.340.

${ }^{55}$ FRIEDLAENDER, Ludwig: Darstellungen aus der Sittengeschichte Roms in der Zeit von August bis zum Ausgang der Antonine, Bd. II, 9. Aufl., Verlag von S.Hirzel, Leipzig, 1920, s.137; GREENIDGE, s.7, s.67 vd., s.124; KASER, RP I, s.274; WIEDEMANN, Thomas: Emperors and Gladiators, Routledge, London and New York, 1995, s.29; DUNKLE, Roger: Gladiators: Violence and Spectacle in Ancient Rome (Gladiators), Routledge, London and New York, 2008, s.35; TÜRKOĞLU ÖZDEMİ, s.103, s.149, s.154. ${ }^{56}$ GREENIDGE, s.7, s.67 vd.; UMUR, Ziya: Roma Hukuku, Tarihî Giriş- Kaynaklar-Umumî Mefhumlar-Hakların Himayesi (Roma Hukuku), Filiz Kitabevi, İstanbul, 1984, s.395.

${ }^{57}$ Infamia'dan kaynaklanan kısıtlamalarla ilgili ayrıntılı bilgi için bkz. GREENIDGE, s.154 vd.; TÜRKOĞLU ÖZDEMIR, s.28 vd.

${ }^{58}$ GREENIDGE, s.68; TÜRKOĞLU ÖZDEMIR, s.103.

${ }^{59}$ Yunan tarzı atletizm yarışmalarının (agones) karşılığı olarak Latince certamina athletarum teriminin kullanımı için bkz. MANN, s.151, s.159; Remijsen de Yunancadaki agon teriminin Latince karşılığının certamen olduğunu belirtmektedir, REMIJSEN, s.328.

${ }^{60}$ D.3.2.4.pr. (Ulp. 6 ad ed.); GREENIDGE, s.125; CROWTHER, Sport, s.84; REMIJSEN, s.130, s.328; yazitlarda ve sanat eserlerindeki sporcu tasvirleri saygı ifade eden nitelik taşımaktadır ve özgür insanlar olarak sporcuların, gösteri sanatlarıyla uğraşan oyuncular, gladyatörler gibi kimselerden daha yüksek bir sosyal statüye sahip olduğu görülmektedir, KYLE, Sport, s.314.

${ }_{61}$ D.3.2.4.pr. (Ulp. 6 ad ed.); WACKE, s.441; TÜRKOĞLU ÖZDEMIR, s.155; kentlerde bulunan onurlandırma yazıtlarından anlaşıldığı kadarıyla, bir sporcunun kazandığı galibiyetin ona onur ve övünç kazandırdığı, ayrıca sporcunun heykelinin ve onurlandırma yazıtının kentin en merkezi yerlerinde halka sergilendiği belirtilmektedir, ÇOKBANKİR ŞENGÜL, Nurşah: “Antikçağda Küçükasya'daki Sporcular: Sosyal Durumları, Profesyonellik ve Kentler”, Cedrus, 1, 2013, s.156 (http://proje.akdeniz.edu.tr/mcri/cedrus/1-2013/cedrus-9-nursah_cokbankir_sengul-

antikcagda_kucuk_asyadaki_sporcular_sosyal_durumlari_profesyonellik_ve_kentler.pdf) (DOI: 10.13113/CEDRUS/20131683) (Erişim tarihi:08.09.2020).

${ }^{62}$ TÜRKOĞLU ÖZDEMIR, s. 155 .

${ }^{63}$ Calıșmamızda Digesta'dan yapılan alıntılarda ve çevirilerde yararlanılan kaynaklar: OTTO, Carl Eduard/SCHILLING, Bruno/SINTENIS, Carl Friedrich Ferdinand: Das Corpus Juris Civilis in's Deutsche Übersetzt von einem Vereine Rechtsgelehrter, Verlag von Carl Focke, Bd. I, 2. Aufl., Leipzig, 1839, Bd. II, Leipzig, 1831, Bd. IV, Leipzig, 1832; WATSON, Alan: The Digest of Justinian, vol. I-II, University of Pennsylvania Press, Philadelphia, 1998; BEHRENDS, Okko/KNÜTEL, Rolf/KUPISCH, Berthold/SEILER, Hans Hermann: Corpus Iuris Civilis, Text und Übersertzung, auf der Grundlage der von Theodor Mommsen und Paul Krüger besorgten Textausgaben, Bd. II (1-10), C.F. Müller juristischer Verlag, Heidelberg, 1995; KNÜTEL/KUPISCH/SEILER/BEHRENDS, Bd. IV (21-27), Heidelberg, 2005.

${ }^{64}$ Söz konusu emirnamenin hangi tarihte çıkartıldığ tam olarak bilinmemekle birlikte M.S.293 y1lından sonra çıkartıldığı savunulmaktadır, REMIJSEN, s.212, dn. 66.

${ }^{65}$ GREENIDGE, s. 125 .
} 
“Atletlerin kamusal görevlerden muaf tutulması ancak bütün yaşamları boyunca, biri Roma'da veya Antik Yunanistan' da kazanılmış olmak koşuluyla, kutsal yarışmalarda ${ }^{66}$ rakiplerine rüşvet vermeden veya onlardan satın almadan en az üç zafer tacı kazandıklarını ispat etmeleri koşuluyla mümkündür." 67

Zafer kazanan atletlere maddî değeri yüksek mal veya para ödülleri verilirdi ve bu sayede atletler belirli bir refaha kavuşurlard ${ }^{68}$. Bunun yanı sıra zafer kazanan atletler, zafer tacı alır, adlarına yazılan şiirlerle kutlanır, heykel ve kitâbelerle ölümsüzleştirilir ${ }^{69}$ ve onlara çeşitli kamusal yükümlülüklerden muaf tutulmak gibi pek çok ayrıcalık tanınırdi ${ }^{70}$. Bazen yerel meclislerde kendilerine makam ve oy hakkı tanınarak onurlandırılırlardı ${ }^{71}$. Dolayısıyla başarılı geçen bir atletizm kariyeri kaydedeğer bir saygınlığın yanı sıra sosyal ve ekonomik anlamda yükselme olanağı sağlamaktaydi ${ }^{72}$.

\section{PROFESYONEL ATLETLERIN ÖDÜNÇ ILISSKILERINE GIRMELERINE YOL AÇAN SEBEPLER}

Profesyonel atletlerin bir kısmının üst sınıfa mensup ailelerden gelmeleri dolayısıyla gereken masrafları karşılayabilecek maddî olanaklara sahip olduğu kabul edilse bile atletizm yarışmalarına hazırlanıp katılabilmek için ödünç almak zorunda kalan atletlerin varlığı göz önünde bulundurulduğunda, atletizmi meslek edinenler arasında yetenekli olup beslenme, antrenman ve seyahat masrafları gibi zorunlu harcamaları karşılayabilecek maddi olanaklardan yoksun olanların bulunduğu sabittir. Atletizm kariyerini seçen bir kimsenin toplumsal ve ekonomik olarak yükselme olanağı bulunmasına rağmen, bu kariyer zorlu ve riskli bir seçenekti. Ailesinden gelen malvarlığı veya ekonomik destekten yoksun olan ve bu nedenle geçimini kendisi temin etmek zorunda kalan bir atlet katıldığı yarışmalarda zafer kazanamadığı müddetçe geçimini sağlayamama tehlikesi ile karşı karşıya kalırdı. Çünkü atletizm ve dövüş müsabakalarında genellikle yalnızca birinci gelen atlet ödüllendirilirdi ${ }^{73}$. Yani bir atlet ya kazanan olurdu veya kaybeden, ikinci veya üçüncü sırayı alana herhangi bir ödül verilmesi söz konusu olmazdi ${ }^{74}$. Bu nedenle düşük gelire sahip bir aileden gelen bir atletin hayatını ekonomik açıdan bağımsız bir şekilde sürdürebilmesi katıldığı müsabakalarda zafer kazanması koşuluna bağlıydı. Büyük turnuvalardan zaferle ayrılabilmek için ise atletlerin tam bir adanmışlık içinde yıllarca düzenli olarak antrenman yapmaları ve belirli bir beslenme düzenini takip ederek yeterli ve sağlıklı beslenmeleri gerekmekteydi ${ }^{75}$. Bir atlet büyük yarışmalara katılmadan önce çok sayıda yerel yarışmaya katılmak zorundaydı ve bu durum çok fazla seyahat etmeyi gerektirmekteydi. Eski dönemlerdeki yolların ve ulaşım araçlarının elverişsizliği nedeniyle bu seyahatlar çok zahmetliydi, çok zaman alıyordu ve çok masraflıydi ${ }^{76}$. Bir atletin geçimini sağlamak için başka bir iş yapmasına yetecek kadar zamanı kalmıyordu ${ }^{77}$. Atletler için bir başka önemli gider de, bütün

\footnotetext{
66 "Kutsal yarışma" kavramı ve hangi yarışmaların bu kategoriye girdiğiyle ilgili olarak bkz. FRIEDLAENDER, s.158 vd.; REMIJSEN, s.52, s.59, s.209 vd.

67 Calıșmamızda Codex'ten yapılan alıntılarda ve çevirilerde yararlanılan kaynak: OTTO, Carl Eduard/SCHILLING, Bruno/SINTENIS, Carl Friedrich Ferdinand: Das Corpus Juris Civilis in's Deutsche Übersetzt von einem Vereine Rechtsgelehrter, Bd. VI, Verlag von Carl Focke, Leipzig, 1832.

${ }^{68}$ WACKE, s.441; BERTLING, Christoph/WASSONG, Stephan: "Striving for Athletic Excellence: A Core Value and Challange for the Profile of the Ancient and Modern Olympic Games", The International Journal of the History of Sport, 33(4), 2016, s.435, DOI: 10.1080/09523367.2016.1143461 (http://dx.doi.org/10.1080/09523367.2016.1143461) (Erişim tarihi: 08.09.2020); PLEKET, Inscriptions, s.103.

${ }^{69}$ FRIEDLAENDER, s.159; bir atlet için dikilecek heykelin veya yazılacak şiirin giderlerini ya bizzat atlet ya da adına oyunlara katıldığı kent karşılardı, BERTLING/WASSONG, s.435; atletlerin onuruna dikilecek heykellerin bile küçük bir servete mal olduğu ve M.Ö 4. yüzyılda böyle bir heykel için yaklaşık 3000 drahmi (drakhme) harcamak gerektiği belirtilmektedir, JAKAB, Éva: "Geld und Sport, Rezeption griechischer Topoi in der römischen Jurisprudenz”, Revue Internationale de Droits de l'Antiquité (RIDA), 59, 2012, s.96, dn. 23.

${ }^{70}$ WACKE, s.441, dn. 16; ayrica bkz. FRIEDLAENDER, s.158; ÇOKBANKİR ŞENGÜL, s.158 vd.; PLEKET, Inscriptions, s.103. ${ }^{71}$ FRIEDLAENDER, s.159; PLEKET, Soziologie, s.74; WACKE, s.441; REMIJSEN, s.222; BERTLING/WASSONG, s.435.

${ }^{72}$ PLEKET, Soziologie, s.71 vd., s.75 vd.; WACKE, s.441; ZIMMERMANN, Reinhard: The Law of Obligations-Roman Foundations of the Civilian Tradition, Oxford University Press, Oxford, 1996, s.186 vd.; REMIJSEN, s.221 vd.

73 Olympia'da ve Yunanistan'da düzenlenen diğer "taç ödüllü” veya "kutsal" oyunlarda yalnızca birinci gelenler ödüllendirilirdi, CROWTHER, Athletics, s.97; ayrıca bkz. ZIMMERMANN, s.187.

${ }^{74}$ MILLER, s.19; müsabakalarda ikinci ya da üçüncü sırayı alanların antik olimpik oyunların son gününde verilen ziyafete bile davet edilmediği ve yalnızca zafer kazananların bu ziyafete katılabildiği belirtilmektedir, BERTLING/WASSONG, s.435; antik dünyadaki bu anlayıșın izlerine günümüzde de rastlanmaktadır. Amerikan futbolu takımlarından Green Bay Packers'ın tanınmıș eski koçu Vince Lombardi'ye atfedilse de (CROWTHER, Sport, s.57 vd.; ÇOKBANKİR ŞENGÜL, s.159) aslında ilk olarak UCLA Bruins Amerikan futbolu takımı koçu Henry Russell Sanders tarafından söylenmiş şu sözler bu anlayışın günümüze yanısıması olarak gösterilebilir: "Kazanmak her şey değildir, o yegâne şeydir." ("Winning isn't everything, it's the only thing.") (https://en.wikipedia.org/wiki/Winning_isn\%27t_everything;_it\%27s_the_only_thing) (Erişim tarihi: 08.09.2020); istisnai olarak bazı büyük oyunlarda (örneğin M.Ö. 4. yüzyılın ilk yarısında Atina'nın Panathenaea oyunlarında) ikinci gelenlere de ödül verildiği belirtilmektedir, CROWTHER, Athletics, s.99; GOLDEN, s.viii.

${ }^{75}$ WACKE, s.442; ZIMMERMANN, s.187; KYLE, Sport, s.203.

${ }^{76}$ JAKAB, s.97.

${ }^{77}$ JAKAB, s.97; KYLE, Sport, s.203; BERTLING/WASSONG, s.435
} 
spor dalları için aynı pahalılıkta olmasa da, antrenman masrafları idi ${ }^{78}$. Koşu yarışmalarına katılacak bir atlet için, doğuştan gelen yetenek iyi bir antrenörden çok daha önemli olmasına rağmen, dövüş sporları veya pentathlon için daha teknik bir antrenman programı (örneğin firlatma teknikleri, güreş pozisyonları, vb.) takip etmek gerekirdi. Bununla birlikte koşu yarışmalarında mücadele etmek, dövüş sporlarında mücadele etmekten göreceli olarak daha pahalıydı, zira seyahat masrafları hemen hemen aynı olmakla birlikte koşu yarışları için verilen ödüller dövüş sporlarındakine oranla önemli ölçüde düşüktü79 . Örneğin Anadolu'da Aydın ili Karacasu ilçesi sınırları içerisindeki Aphrodisias'ta bulunan ödül listesinde dövüş sporları için daha yüksek ödüllerin belirlenmiş (pankration'da kazanan için 3000 drahmi (drakhme), güreş ve boksta 2000 drahmi, koşu ve diğer atletizm yarışmaları için ise 1250-500 drahmi) olduğu görülmektedir ${ }^{80}$.

Bunun yanı sıra atletin yarışmalara katılıp ödül kazanmak için gösterdiği çabanın tamamen sonuçsuz kalma olasılı̆̆ı da vardı. Hayatını rahat koşullarda sürdüren varlıklı üst sınıf mensuplarından olmayan genç bir atlet, ilk koşu yarışını kazanmış olsa bile, ilk büyük yarışını kazanıncaya kadar geçimini nasıl sağlayacaktı? Atletizmi meslek edinip geçimini bu yolla sağlamak isteyenler için kariyerlerinin başlangıcında para temin etmek aşılması zor bir sorundu ${ }^{81}$. $\mathrm{Bu}$ nedenle genç ve yetenekli bir atlet için, sarf ettiği bütün çabanın sonuçsuz kalma riskini üstlenmeye hazır bir sponsor bulup ondan ödünç alarak masraflarını karşılama olanağı elde etmesi hayatî bir önem taşıyordu ${ }^{82}$.

\section{PROFESYONEL ATLET İLE KURULAN ÖDÜNÇ İLIŞKISISINE BENZEYEN HUKUKÎ İLIŞKILER}

İmparator Marcus Aurelius dönemindeki (M.S. 161-180) hukukçulardan olan Quintus Cervidius Scaevola, Digesta'nın deniz ödünçlerine ilişkin olan 22. kitabının 2. faslında yer alan bir parçada profesyonel bir atletin, geçimini sağlamak ve antrenman programı ve kendisi için gereken spor malzemeleriyle ilgili masraflarını karşılayabilmek amacıyla para ödünç almasına ilişkin bir örnek vermektedir ${ }^{83}$ :

\section{D.22.2.5.pr. (Scaevola 6 resp.)}

"...nec dubitabis, si piscatori erogaturo in apparatum plurimum pecuniae dederim, ut, si cepisset, redderet, et athletae, unde se exhiberet exerceretque, ut, si vicisset, redderet."

"...av malzemesi için harcama yapmak isteyen bir balıkçıya, (balık) tuttuğunda geri ödemesi kaydıyla veya bir atlete iaşesi ve antrenmanları için, (zafer ve ödül) kazandığında geri ödemesi kaydıyla çok miktarda para ödünç verdiğimde de (condictio açılabileceğinde) şüphe yoktur."

Scaevola, bu örnekte dar gelirli ve toplumun alt tabakasından olan bir profesyonel atleti ele almaktadır. Aynı parçada atletin yanı sıra, geçimini balıkçılıkla sağlayan ve av malzemelerini aldığı ödünçle temin eden balıkçı örneğine de yer verilmektedir. Örnekteki balıkçılar da tıpk1 atletler gibi genellikle toplumun alt tabakasına mensup olan dar gelirli kimselerdi ve özellikle orkinos (thynnus) gibi büyük balıkların avlanmasında kullanılan kayık ve ağ gibi malzemeler oldukça pahalıyd ${ }^{84}$. Bir balıkçının kayık ve ağ dışında giderlerinin ortaya çıkması da söz konusu olabilirdi. Çok büyük bir balık avlandığında bu balık ancak çifte koşulmuş sığırlar tarafindan denizden çekilebilirdi ve bunları da balıkçının sağlaması gerekirdi. Balıkçılar işlerinin gerektirdiği masrafları karşılayabilmek için oldukça yüksek meblağlarda paraya ihtiyaç duyarlardı ve bu parayı da ödünç alarak temin etmek zorunda kalırlard1 ${ }^{85}$.

Balıkçının almış olduğu ödüncü geri ödeme yükümlülüğü, atletin katıldığı müsabakalarda birinci olup ödül kazanması koşuluna bağlı geri ödeme yükümlülüğüne benzer şekilde, yalnızca balık tutabilmiş olması hâlinde doğacaktır. Her iki olayda da geri ödemenin bağlı olduğu koşulun gerçekleşmemesinin riskini ödünç veren üstlenmektedir ${ }^{86}$. Bu iki örneğe benzer şekilde deniz ödüncünde de (fenus nauticum) ödüncün geri ödenmesi, geminin yüküyle birlikte limana güvenli bir şekilde ulaşmasına bağlıydı. Deniz ödüncünde ödüncün geri ödenmesi, geminin firtına nedeniyle batması veya korsan saldırısı gibi meydana gelmesi tamamen tarafların kontrolü dışında olan olayların gerçekleşip gerçekleşmemesine bağlıdır. Yani deniz ödüncünde ödüncün

\footnotetext{
${ }^{78}$ REMIJSEN, s.221; KYLE, Sport, s.320.

${ }^{79}$ REMIJSEN, s.221.

${ }^{80}$ PLEKET, Soziologie, s.71; aynı yönde bkz. JAKAB, s.96.

${ }^{81}$ PLEKET, Soziologie, s.76; WACKE, s.442.

${ }^{82}$ ZIMMERMANN, s.187; aynı yönde bkz. JAKAB, s.98.

${ }^{83}$ WACKE, s.442; ZIMMERMANN, s.186.

${ }^{84}$ WACKE, s.443.

${ }^{85}$ VON GLÜCK, Christian Friedrich: Ausführliche Erläuterung der Pandecten nach Hellfeld, Bd. 21, 1, Johann Jacob Palm, Erlangen, 1820 , s. $165 \mathrm{vd}$.

${ }^{86}$ WACKE, s.444
} 
geri ödenmesi sonucunu doğuracak koşulun gerçekleşmesinin tarafların iradesine bağlı olmadığ1 görülmektedir ${ }^{87}$. Atlet ve balıkçı örneklerinde ise ödüncün geri ödenmesinin gerekip gerekmediği, belirli bir ölçüye kadar, ödünç alan tarafından belirlenmektedir. Başka bir ifadeyle ödüncün geri ödenip ödenmeyeceğinde ödünç alanın iradesi kısmen de olsa belirleyici olacaktır ${ }^{88}$. Balıkçının, balık tutmak için gayret göstermesi, atletin zafer kazanmak için düzenli bir biçimde antrenman yapması, beslenme ve uyku düzenine dikkat etmesi ve zahmetli seyahatleri göze alıp yarışmalara katılması gerekecektir. Balık tutulması ve zafer kazanılmasına rağmen, alınan ödünç geri ödenmezse, ödünç veren tarafindan ödünç alana condictio $^{89}$ açılabilecektir.

Wacke, Scaevola'nın D.22.2.5.pr.deki metninde yer alan atletlere ve balıç̧lara verilen ödünçlerle deniz ödünçleri arasında bir benzerlik olduğu görüşündedir ${ }^{90}$. Ancak Jakab, bu metni Wacke'nin yorumladığından daha farklı bir şekilde değerlendirmektedir. Jakab'a göre deniz ödüncü ile bir atlete verilen ödünç birbirinden tamamen farklıdır ve atlete verilen ödünç, Roma sözleşmeler sisteminde herhangi bir kategoriye kolayca yerleştirilemeyecek atipik bir anlaşma niteliğindedir. Jakab, atlet zafer kazansa bile hukuken ödüncü geri ödeme yükümlülüğünün olmadığını, atlete verilen ödüncün faizsiz bir hatır ödüncünü andırdığını ve alınan ödüncün geri ödenmesine yönelik olarak atlet üzerinde yalnızca toplumsal bir baskının söz konusu olabileceğini savunmaktadır. Atletin aldığı ödüncü geri ödemesi, onu desteğini gördüğü sponsoruna karşı taşıdığ1 kişisel-ahlâkî yükümlülüğünden kurtarma amacına hizmet etmektedir. $\mathrm{Bu}$ durumda da zaten faiz söz konusu olmayacak, yalnızca anaparanın iadesi gündeme gelecektir ${ }^{91}$. Yani, Jakab'a göre, atlet zafer kazansa ve buna rağmen aldığı ödüncü geri ödemese bile ona karşı kural olarak condictio açılamayacaktır. Zira atletlere ödünç verenler, onları vicdansızca sömürme amacıyla hareket eden yatırımcılar değildirler. Ödünç vererek bir anlamda sponsorluk yapanlar daha çok hiçbir kazanç amacı gütmeden ve genellikle verdikleri ödüncü geri alma beklentisi içine girmeden atletleri fedakârca teşvik eden cömert ve iyiliksever kimselerdir. $\mathrm{Bu}$ nedenle verdikleri ödünçlerde de faiz almayı genellikle düşünmezler ve "hatır ödüncü (Freundschaftsdarlehen-dayanışma ödüncü-dostluk ödüncü)" niteliği taşıyan bu ilişkiden yalnızca bir "namus borcu (Ehrenschuld-şeref borcu)" doğar". Jakab, ödül kazanan atlete karş1 condictio'nun sadece ödünç verenin haklı bir sebebe dayanarak ödünç verdiğine pişman olması durumunda açılabileceğini savunmaktadır. Bu haklı sebeplere örnek olarak atletin ödünç verene ağır hakaretlerde bulunmasını, ona karşı kötü veya ahlaksızca davranmasını göstermektedir ${ }^{93}$. Jakab, ortaya koyduğu ödünç geri ödenmediğinde dava açmayı ve faiz almayı aklından geçirmeyen hayırsever ve âlicenap sponsor tablosunu ikna edici delillerle destekleyememiştir. Ayrıca bir yandan konuyla ilgili temel metin olan D.22.2.5'in Digesta'da deniz ödünçlerinin ele alındığı fasılda yer alması Jakab'ın argümanlarını zayıflatmaktayken diğer yandan hem bu metnin hem konuya ilişkin diğer metinlerin içeriği Jakab'ın görüşlerini desteklemekten çok onun görüşleriyle çelişmekte ve Wacke'nin yaklaşımıyla daha çok örtüşmektedir. Wacke'nin görüşünü onaylar nitelikte olduğu kabul edilebilecek metinlerden biri Digesta'nın 42. kitabının 1. faslının 40. parçasında yer alan metindir (D.42.1.40 (Papinianus 10 resp.). Bu metne göre bir atlet katıldığı yarışmalarda zafer kazanmış olmasına rağmen almış olduğu ödüncü ${ }^{94}$ kendi rızasıyla geri ödemezse, ödünç veren ona borcunu ifa etmesi için dava açtıktan sonra icra edilebilir bir hükme dayanmak suretiyle alacağının karşıllğı olarak galibiyet ödülleri üzerine haciz koydurabilirdi.

\footnotetext{
${ }^{87}$ ZIMMERMANN, s.186.

${ }^{88}$ ZIMMERMANN, s.186; Bu tip işlemler, kumar niteliği taşımadıkları sürece, tamamen geçerli sayılırdı, bkz. D.22.2.5.pr. (Scaevola 6 resp.): “...si modo in aleae speciem non cadat...” : “..., işlemin kumar niteliği taşımaması şartıyla...”.

${ }^{89}$ Condictio: Formula'snda borcun sebebi gösterilmeyen ve bir verme (dare) borcuna ilişkin olan dar hukuk davası. Bu davalarla belirli bir miktar para veya belirli bir şeyin verilmesi talep edilirdi. Tüketim ödüncü sözleşmesinde ödünç alanın borcunu yerine getirmemesi hâlinde, konusu verme borcu olan bir stipulatio için ve sebepsiz zenginleşme hâllerinde bu davaya başvurulurdu, UMUR, Lügat, s.43; RADO, s.51.

${ }^{90}$ WACKE, s.444; Wacke'nin savunduğu görüşün daha eski taraftarlarından sayılabilecek olan Glück, atletlere ve balıkçılara verilen ödünçlerin "deniz ödüncü benzeri” (foenus quasi nauticum) olarak adlandırıldı̆̆ını belirtmiştir, VON GLÜCK, s.153; Litewski de D.22.2.5.pr.nin çıkış noktasının deniz ödüncüne dayandığını savunmaktadır, LITEWSKI, Wieslaw: "Römisches Seedarlehen", Rivista Internazionale di diritto romano e antico (IURA), 24, 1973, s.164.

${ }^{91}$ JAKAB, s.123.

${ }^{92}$ JAKAB, s. 125.

${ }_{93} \mathrm{JAKAB}$, s. 123 .

${ }^{94}$ Jakab, burada atlete zafer kazandığında geri ödemesi koşuluyla verilen ödüncün değil şarta bağlı olmayan alelâde bir ödüncün söz konusu olduğunu savunmaktadır, JAKAB, s.124; kanaatimizce bu metin, atletlere yalnızca başarılı olduklarında geri ödemeleri koşuluyla verilmiş ödünçler için de uygulanabilecek hatta muhtemelen öncelikle bu tip ödünçler göz önünde bulundurularak düzenlenmiş olan bir metindir.
} 
D.42.1.40 (Papinianus 10 resp.)

"Commodis praemiorum, quae propter coronas sacras praestantur, condemnato placuit interdici et eam pecuniam iure pignoris in causam iudicati capi."

"Hükümlünün (Borcu ödemeye mahkûm edilenin) "kutsal yarışmalarda" kazanılan ödüllerden elde edilen geliri alması engellenir ve bu paraya ilâm borcunun ifası amacıyla rehin olarak el koyulduğu kabul edilmektedir."

$\mathrm{Bu}$ metinde bahsi geçen atletin malvarlığına haciz konulması konusu özellikle önem taşımaktadır çünkü en azından bazı atletlerin, kendilerine asylia ${ }^{95}$ imtiyazı tanınması suretiyle, şahıs üzerindeki icradan kurtarılabildikleri bilinmektedir ${ }^{96}$. Yani bu imtiyaza sahip atletlerin şahısları üzerinde icra söz konusu olmamakla birlikte atletler yalnızca malvarlıkları ile olsa da sorumlu tutulabileceklerdir. Bu metinde de görüldüğü gibi bir atlet, geri ödemenin başarılı olma ve zafer kazanma koşuluna bağlı olduğu bir ödünç alıp zafer kazanmasına rağmen almış olduğu ödüncü geri ödemezse ona karşı dava açılabilecek ve borcu ödemeye mahkûm edilen atletin almış olduğu ödüller üzerine haciz konulabilecektir.

\section{PROFESYONEL ATLETE VERILEN ÖDÜNCÜN HÜKÜMLERİ VE FAİZ MESELESİ}

Bir önceki başlık altında ele aldığımız ve bizim de benimsediğimiz görüş uyarınca atlet zafer kazanamazsa, balıkçı balık tutamazsa, gemi sefer esnasında batarsa veya seferini tamamlayamazsa, ödünç veren parasını geri alamazd ${ }^{97}$. Başka bir ifadeyle atlet, almış olduğu ödüncü yalnızca bir zafer kazanabilirse, balıkçı balık tutabilirse, gemici de gemi varış limanına sâlimen varabilirse geri ödemek zorundayd ${ }^{98}$. Bu belli ki büyük bir riskti. Atletlere yapılan yatırım, deniz yolculuklarının veya balıkçıların av malzemelerinin finanse edilmesinden çok daha riskli bir yatırımdı. Zira balıkçının bir şeyler tutması veya geminin sâlimen varış limanına ulaşması genellikle beklenen bir durumdu. Bu durumların aksine, genç bir atletin daha sonraki büyük yarışmalarda bir zafer kazanıp kazanamayacağı ise tamamen belirsizdi. Ayrıca balıkçılar arasında artan rekabetin, her bir balıkçının av kotasını düşürme olasılığı olsa bile, atletler arasında artan rekabet her bir atletin zafer kazanma olasılığını çok daha fazla azaltırdı, çünkü yarışmaların yalnızca tek galibi olurdu ${ }^{99}$. Bu nedenle girdiği riskin karş1lığı olarak, ödünç verene, tıpkı deniz ödüncünde olduğu gibi ${ }^{100}$, normal oranlardan daha yüksek oranda faiz talep etme hakk1 tanınmışt ${ }^{101}$. Buradaki faizin ayrıca stipulatio ile kararlaştırılmış olması zorunluluğu da yoktu ${ }^{102}$ :

D.22.2.5.1 (Scaevola 6 resp.)

"In his autem omnibus et pactum sine stipulatione ad augendam obligationem prodest."

"Fakat bütün bu durumlarda stipulatio olmaksızın şekle bağlı olmayan bir sözleşmenin (pactum) yapılması ile yükümlülüğün kapsamı genişletilebilir.”

İlgili Digesta metninde, faiz talebinde bulunulabileceği açık olarak ifade edilmiş değildir. Jakab, metinde faizden açıkça söz edilmemesine dayanarak, atletlere verilen bu gibi ödünçlerde faizin söz konusu olamayacağını, bu gibi ödünçlerin geri ödenmesinin atletin inisiyatifine bırakıldığını ve bunların yalnızca hatır ödüncü olarak değerlendirilmesi gerektiğini ileri sürmektedir ${ }^{103}$. Bununla birlikte metinde faize yönelik açık bir ifade bulunmasa bile bir önceki paragrafta (D.22.2.5.pr) alacaklının "(verilen) paranın biraz daha fazlasını" ("insuper aliquid praeter pecuniam (quod dederit)") alabileceğinden ${ }^{104}$ ve D.22.2.5.1'de de bir pactum ile “yükümlülüğün kapsamının genişletilebileceği”"nden ("ad augendam obligationem”)

\footnotetext{
${ }^{95}$ Çok eski dönemlerde yabancıların bizzat şahıslarına veya malvarlıklarına zorla el konulması mümkündü çünkü yabancıların (tâbi oldukları şehir devletiyle bulundukları şehir devleti arasında bir anlaşma yoksa) herhangi bir hukukî korumadan yararlanmaları mümkün değildi. Antik Yunan'da bir kişiyi kendisine yönelebilecek saldırılardan veya mallarının ya da kendisinin zorla alıkonulmasından koruyan ayrıcalığı ifade etmek için asylia kavramı kullanılmaktaydı, SZANTO, Emil: “A Halbband, (Paulys Realencyclopädie der classischen Altertumswissenschaft), Alfred Druckenmüller Verlag, Stuttgart, 1896, s.1879 vd.

${ }^{96}$ WACKE, s.450.

${ }^{97}$ WACKE, s.444.

${ }^{98}$ ZIMMERMANN, s.186.

${ }^{99}$ WACKE, s.447.

${ }^{100}$ Deniz ödüncünde faiz için bkz. BILLETER, Gustav: Geschichte des Zinsfusses im griechisch-römischen Altertum bis auf Justinian, Druck und Verlag von B. G. Teubner, Leipzig, 1898, s.242 vd.; LITEWSKI, s.152 vd.

${ }^{101}$ OTTO/SCHILLING/SINTENIS, Bd. II, s.618, dn. 61; WACKE, s.442; ZIMMERMANN, s.187.

${ }^{102}$ KASER, RP II, s.317, dn. 17; LITEWSKI, s.168; WACKE, s.444; ZIMMERMANN, s.187.

${ }^{103}$ JAKAB, s. 122 .

${ }^{104}$ D. 22.2.5.pr. (Scaevola 6 resp.): "Periculi pretium est et si condicione quamvis poenali non exsistente recepturus sis quod dederis et insuper aliquid praeter pecuniam, si modo in aleae speciem non cadat:..." : "Eğer işlem kumar niteliği taşımıyorsa, cezai şart olarak kararlaştırılmış olan koşul gerçekleşmediğinde bile verdiğin (parayı) ve verdiğinden daha fazlasını geri alabiliyorsan, (bu durumda) bir riski üstlenmenin bedeli (karşılığı) söz konusudur."
} 
bahsedilmektedir ${ }^{105}$. Metinde faiz kelimesi açıkça geçmese de "yükümlülüğün kapsamının genişletilmesi" ifadesi, faiz olarak yorumlanmaya müsaittir. Metindeki ifade tarzından, faizlerin belirli vadelerin gelmesiyle muaccel olmaktan çok, ödünç verilen anapara ile birlikte bir seferde ödenecek bir ilave veya fazlalık niteliği taşıdığ 1 sonucuna da varılabilir. Bu fazlalığın miktarı, tamamen ödüncün süresine göre belirlenebilirdi, ancak bunun elde edilmesi de başarı koşulunun gerçekleşmesine bağlıydı ve alacaklı bu koşulun gerçekleşmesinden önce faiz alamazd ${ }^{106}$. Diğer yandan alacaklının üstlendiği riskin karşılığ (periculi pretium) olarak görülen fazladan miktar için kullanılan insuper aliquid terimi o kadar genel bir anlama sahiptir ki bu terim yalnızca maktu bir faiz şeklinde mülahaza edilmez, faiz dışındaki menfaatleri de kapsıyor olabilir ${ }^{107}$. Ayrıca, her ne kadar hakkında kesin bir bilgiye sahip olmasak bile, alacaklının, atlet tarafından elde edilmiş zafer kazancının belli bir yüzdesine ortak olması ihtimali düşünülebilir ${ }^{108}$.

Bir atletin antrenman ve eğitim masraflarının, geri ödenmesi başarılı olma koşuluna bağlı olan böyle bir ödünç sözleşmesi ile karşılanması onun için oldukça avantajlı bir durumdu. Atlet böyle bir ödünç aldığında hiçbir parasal riske girmemiş oluyordu. Zafer kazanmadığı müddetçe almış olduğu parayı alacaklıya geri ödemek zorunda değildi. Zafer elde etmesi sonucunda kazanmış olduğu ödülün değeri, almış olduğu ödünç tutarından daha azsa, geri ödeme yükümlülüğü muhtemelen, balıkçı ödüncünde olduğu gibi, almış olduğu ödüncün ödüle karşılık gelen uygun bir kısmıyla sınırlandırılmış olmalıdır. Diğer yandan atlet, ödünç verene ekonomik açıdan bağımlı hale gelebilirdi. Atletin borcu ne kadar fazla olursa bu bağımlılığın da o derece artacağı söylenebilir ${ }^{109}$. Yüksek miktarlı veya uzun vadeli bu tip bir ödünçte ödünç verenin ve alanın durumları, günümüze çok da uzak olmayan bir zamanda, 20. yüzyılın son çeyreğinde profesyonel boksörlere ödünç verenlerin ve ödünç alan boksörlerin durumuna kısmen de olsa benzerlik göstermektedir. Konuya ilişkin bir örnek, 1976 Montreal Olimpiyatlarında altın madalya kazandıktan sonra profesyonel olmaya karar veren ünlü boksör Sugar Ray Leonard'dır. Leonard, profesyonel kariyerinin başında giderlerini karşılayabilmek için 4 yıl içinde $\% 8$ faizle geri ödemek üzere 21.000 dolar ödünç almıştır ${ }^{110}$. Ancak her spor dalında sporcuya ödünç verilmesi söz konusu değildir. Günümüzde profesyonel sporcuların pek çoğu (futbolcular, basketbolcular, voleybolcular, vb.) hizmet sözleşmesiyle çalışan bağımlı çalışanlar (işçiler) olarak genellikle sabit bir maaş almaktadırlar. Dolayısıyla hiçbir geri ödeme yapma yükümlülükleri yoktur ${ }^{111}$.

Profesyonel atletlere verilen ödünçlere ilişkin kaynaklarda, ödüncün belirli bir miktarla veya süreyle sınırlandırılmasına ilişkin bir örnek yoktur. Yukarıda zikredilmiş olan D.22.2.5.pr.de yer alan "plurimum pecuniae" teriminin muğlak olması, bu konuyu her ihtimale açık bırakmaktadır. Atlete bir kerelik bir tutar (meblağ) yerine maaş gibi devamlı ödeme yapılması da ihtimal dâhilindedir. Olimpik oyunlara katılacak olanların, oyunların başlamasından otuz gün önce gözetim altında yapılan resmî antrenmanlar için Olympia'da bulunma zorunlulukları vard1 ${ }^{112}$. Bunun dışında yarışlara hazırlanabilmek için memleketlerinde de 10 ay boyunca antrenman yapmış olmaları gerekiyordu ${ }^{113}$. Eğitim masraflarının, belirli bir yarışma öncesindeki bu kısıtlı antrenman süresi ile sınırlı olacak şekilde mi yoksa yıllar boyunca sürecek şekilde mi karşılanıp karşılanmadığını tespit etmek mümkün değildir ve bu sadece ödünç işleminin taraflarının bu konuyu nasıl kararlaştırmış olduklarına bağlıdır. Alacaklı, atletin eğitim masraflarının tamamını karşılayabileceği gibi yalnızca bir kısmını da üstlenebilir ve geri kalanınını da atletin kendi olanaklarıyla karşılaması kararlaştııılabilirdi ${ }^{114}$.

Antik çağda profesyonel bir atletin karşılaştığı engeller ve mücadele etmek durumunda olduğu zorlu koşullar göz önünde bulundurulduğunda, onun ödüncü ve yüksek orandaki faizi geri ödeyebilmek maksadıyla mücadele etmek yerine zafer için çabalamaktan vazgeçip

\footnotetext{
105 WACKE, s.444

106 WACKE, s.444

${ }^{107}$ WACKE, s.444; Litewski, genel bir terim olan periculi pretium teriminin yalnızca faize ilişkin olmadığını, faiz dışında başka menfaatleri de kapsayabileceğini belirtmektedir, LITEWSKI, s.150, dn. 177, s.165.

${ }^{108}$ WACKE, s.444

${ }^{109}$ WACKE, s.445.

${ }^{110}$ LEONARD, Sugar Ray/ARKUSH, Michael: The Big Fight, My Life in and out of the Ring, Viking (Published by Penguin Group), New York, 2011, s.68; ancak bu örnekte Roma hukundakinden farklı olarak, boksör ödüncü yalnızca zafer kazanabilirse değil her halükârda geri ödemekle yükümlüdür. Yine de Roma'dakine benzer şekilde burada da ödünç verenlerin ümitlerini boksörün kazanacağı zaferlere ve paraya bağlamış olmaları söz konusudur.

${ }^{111}$ WACKE, s.446.

${ }^{112}$ MILLER, s.207

${ }^{113}$ PLEKET, Olympic Games, s.406.

${ }^{114}$ WACKE, s.445.
} 
vazgeçmeyeceği sorusu akla gelebilir. Zaferin atlet için maddî bir cazibe taşıması, ancak atletin zafer zonucunda kazanacağı ödülün miktarının, ödünç almış olduğu tutarın, faizi de kapsayacak şekilde, oldukça üstünde olması durumunda mümkün olurdu. Sadece bu durumda ödüncü faiziyle birlikte geri ödedikten sonra kendisine önemli bir miktar kalması söz konusu olurdu ${ }^{115}$. Başarılı bir olimpiyat şampiyonunun çok yüksek miktarda maddî kazanç elde etme olasılığı vardı. Para ödülü ve aynî ödüller, ücretsiz beslenme olanağı ve mensup olunan kentin verdiği maaş gibi pek çok farklı gelir olanağı mevcuttu. Başarılı atletler yıl boyunca yarışmaların yapıldığ birinden diğerine seyahat ederlerdi ${ }^{116}$. Katıldıkları pek çok yarışmada yüzlerce zafer elde ettikten sonra hatırı sayılır bir malvarlığ elde edebilirlerdi ${ }^{117}$. Bu nedenle, profesyonel atlet olarak başarılı geçen bir kariyer, başlangıçta herhangi bir malvarlığı bulunmayan atletlerin bile geçimlerini sağlayacak kadar hatta daha fazla gelir elde etmelerini sağlayabilirdi ${ }^{118}$. Antik dönemin en ünlü atletlerinden olan Theogenes (veya Theagenes) ${ }^{119}, 22$ yılda hiç yenilmeden yaklaşı 1300 zafer $^{120}$ ve para ödülü verilen pek çok yarışma kazanmıştır ${ }^{121}$. Antik dönemdeki atletler için para ödülleri kabul etmek yakışıksız sayılmazd1 ${ }^{122}$, aksine mücadelenin esas amacı buydu ${ }^{123}$. Bundan dolayı zafer kazanmak bir profesyonel atlet için en önemli husustu ve antik dönemdeki profesyonel atletlerin mutlak önceliğiydi ${ }^{124}$. Kazanılabilecek ödül miktarı o kadar fazlaydı ki, bir atlet beslenmesi ve antrenmanı için kullanmış olduğu ödüncü (gerektiğinde geçmiş yıllar için olanları da) rahatlıkla ödeyebilirdi ve ödemeden sonra kendisi için bir miktar kazanç kalırdı. Kendileri de ödünç verecek kadar zenginleşmiş olan atletlerin sayısı hiç de az değildi ${ }^{125}$. Bazıları kendi dallarına sâdık kalıp hâmî olarak, genç yetenekleri ve kendi sporcu loncalarını destekliyorlard ${ }^{126}$.

Bir atletin kazanabileceği maddî ödüllere bakıldığında, sırf almış olduğu ödüncü geri ödememek için zaferden vazgeçmesi olasılığı oldukça düşüktür. Mücadeleden ve zafer elde etmekten vazgeçme olasılığından daha büyük bir tehlike, atletin kazanma olanağı bulunmasına rağmen bu olanaktan menfaat karşıllı̆ında rakipleri lehine vazgeçmesi tehlikesidir. Hatta bu durumda alınan para, yarışmayı kazanamadığı için ödüncü geri ödemek zorunda kalmayacağından dolayı atlet açısından bir ikramiye olarak bile görülebilirdi ${ }^{127}$. Fakat ödüllerin özendiriciliği ve kazanılacak olası bir zaferin maddî ve manevî avantajları bu tip düşüncelere karşı ağır basmakta ve atletler için daha cazip görünmekteydi. Ayrıca ödünç veren, şike yapıldığını fark ettiğinde atlete vermiş olduğu ödüncün iade edilmesini talep edebilirdi. Zira ödüncün geri ödenmesinin dayandığı koşulun fiilen gerçekleşmesi, bu koşulun gerçekleşmemesinde menfaati olan kişi (muhtemel borçlu, yani ödünç almış atlet) tarafindan kötü niyetle engellenirse, koşul gerçekleşmiş sayılırd ${ }^{128}$. Bununla birlikte ödünç alan atlet kendisi şike yapmayıp da kazanacağ 1 zafer başka bir rakibi veya rakibine ödünç veren kişi tarafından şikeyle satın alınmışsa ve

\footnotetext{
${ }^{115}$ WACKE, s.446.

116 Yunan şehirlerinin festival takvimi, sporcuların seyahatlerini ve yarışmalara katılmalarını mümkün kılmak için bu şekilde düzenlenmişti, PLEKET, Soziologie, s.71; WACKE, s.447.

117 ZIMMERMANN, s.187.

${ }^{118}$ REISCH, Athletai, s.2054; PLEKET, Soziologie, s.72.

${ }^{119}$ Theogenes hakkında bilgi için bkz. GOLDEN, s.163; MILLER, s.163 vd.; YOUNG, s.44 vd.; CROWTHER, Sport, s.140 vd.

${ }^{120}$ WACKE, s.447; PLEKET, Olympic Games, s.406; YOUNG, s.106; Golden, Theogenes' in 1200, 1300 veya 1400 zafer kazandığını belirtmektedir, GOLDEN, s.163; Kyle bu sayıyı (antik çağ yazarı Pausanias'ı kaynak göstererek) yaklaşık 1400 olarak vermektedir, KYLE, Olympics, s.33, aynı yönde MILLER, s.213.

${ }^{121}$ PLEKET, Olympic Games, s.406.

${ }^{122}$ MILLER, s.212 vd;; REMIJSEN, s.223; günümüzde de Olimpiyat oyunları ve Dünya şampiyonalarında dereceye girmiş başarılı sporcuların "Spor Hizmet ve Faaliyetlerinde Üstün Başarı Gösterenlerin Ödüllendirilmesi Hakkında Yönetmelik" (RG: 03.11.2010; 27748) hükümleri uyarınca devlet tarafindan ödüllendirilmesi öngörülmüştür.

123 19. yüzyılın sonlarında modern Olimpiyat oyunlarının düzenlenmeye başlamasıyla, "katılmak kazanmaktan daha önemlidir", "evrensel kardeşlik ve barış", "fair play", "firsat eşitliği” gibi değerleri öne çıkartan amatör spor anlayışı bu yaklaşımını antik Yunan atletizminde bulunduğu iddia edilen değerlere dayandırmıştı. Uzun süre kabul görmüş bu yaklaşımın antik çağdaki Olimpiyat yarıșmaları ve atletler için geçerli olmadığı görüşü zamanla ağırlık kazanmıștır. Antik çağda da atletizmle bağdaştırılmıș değerler bulunmakla birlikte, "katılmak kazanmaktan daha önemlidir" prensibinin, "fair play" kavramının ve "para için değil daha yüce değerler için yarışan amatör atlet" anlayışının antik çağa tamamen yabancı olduğu ileri sürülmektedir. Geçimlerini atletizm ile sağlayan üst düzey atletler zafer ve ödül kazanmak için düzenli olarak seyahat edip yarışmalara katılırlardı ve öncelikli amaçları kazanmaktı. Esasen "athletes" kelimesinin de "ödül” anlamındaki "athlon” kelimesinden geldiği ve "ödül için yarışan" anlamını taşıdığı kabul edilmektedir. Dolayısıyla atlet kavramı tanımı itibariyle ödül karşılığı yarışma anlayışını barındırmaktaydı, PLEKET, Games, s.147; YOUNG, s.93; WACKE, s.446; CROWTHER, Sport, s.41.

${ }^{124}$ WACKE, s.446; CROWTHER, Sport, s.56 vd.

125 PLEKET, Soziologie, s.68 vd; WACKE, s.447.

${ }^{126}$ WACKE, s.447.

${ }^{127}$ Günümüzde olduğu gibi antik çağda da müsabakalarda şike yapılması sık rastlanan bir durumdu, WACKE, s.447; MILLER, s.211 vd.; POTTER, s.286 vd.

${ }^{128}$ KASER, RP I, s.257; WACKE, s.448; ZIMMERMANN, s.187; Roma hukukundaki bu prensip günümüz hukukunda da uygulanmaktadır, bkz. TBK md. 175/I: "Taraflardan biri, koşulun gerçekleşmesine dürüstlük kurallarına aykırı olarak engel olursa, koşul gerçekleşmiş sayılır.”.
} 
düzenleme (organizasyon) kurulu bu şekilde kazanılmış olan böyle bir zaferi iptal ettiyse, şart gerçekleşmediği için ödüncü iade etmek zorunda değildi ${ }^{129}$.

\section{SONUÇ}

Antik Roma'da atletizm yarışmalarının düzenlenmesi, atlı savaş arabası yarışları, tiyatro gösterileri ve gladyatör dövüşleri gibi gösterilerden daha sonra, yaklaşık olarak M.Ö. 2. yüzyıldan itibaren gerçekleşmiştir. Atletizm festivallerinin zamanla yaygınlaşması ve sayılarının artması ile birlikte bu konuda hukukî düzenlenmeler yapılması zorunluluğu ortaya çıkmıştır. Bu düzenlemelerden birisi de profesyonel atletlerle yapılan tüketim ödüncü sözleşmelerine ilişsin olan bir Digesta metni olarak karşımıza çıkmaktadır. Çalışmamızda ayrıntılı olarak incelediğimiz bu metinde, ekonomik açidan iyi durumda olmayan bir atletin, antrenman, beslenme ve seyahat gibi masrafları için ödünç almak zorunda kalması sonucunda ortaya çıkan hukukî durum ele alınmıştır.

Profesyonel atletlerin toplumsal ve hukukî statüleri tartışmalara ve farklı görüşlerin ortaya çıkmasına sebep olan bir konudur. Atletizm müsabakalarına katılanların çoğunluğunun Roma değil antik Yunan çevresinden oldukları genellikle kabul edilmektedir. Profesyonel atletlerin daha çok hangi toplumsal sınıfa mensup oldukları konusunda doktrinde farklı görüşler olmasına rağmen, bu atletlerden en azından bir kısmının yeterli ekonomik kaynağa sahip olmadıkları ve bu nedenle antrenman, beslenme ve seyahat gibi masrafları için ödünç almak zorunda kaldıkları görülmektedir. Profesyonel atletlerin hukukî statüsü ile gladyatörler ve sahne sanatçılarınınki arasında önemli bir farklılık göze çarpmaktadır. Yarışmalara katılan profesyonel atletler, şerefsizliğe (infamia) dûçar olan gladyatörler ve sahne sanatçılarından farklı olarak şerefsiz (infamis) ilân edilmezlerdi. Bunun sebebi, atletlerin mesleklerini para kazanmak için değil beceri ve yiğitliklerini ortaya koymak için icra ettiklerinin düşünülmesidir. Atletlerin toplumsal ve hukukî statüsü genel olarak gladyatörler ve sahne sanatçılarından daha iyi olsa bile bu durum Romalıların atletizm müsabakalarına katılmaları için yeterince teşvik edici olmamıştır. Romalıların atletizm yarışmalarına katılma konusundaki çekimser tutumlarında kalabalık önünde performans sergileme hakkındaki genel olumsuz yaklaşımlarının yanı sıra Yunan atletizm yarışmalarında çıplak yarışılması ve bu konudaki olumsuz düşünceleri de belirleyici olmuştur.

Roma hukukukunda, profesyonel bir atlete antrenman masrafları ve beslenmesi için zafer kazandığında geri ödemesi koşuluyla para ödünç verilmesi, olağan tüketim ödüncü sözleşmelerinden farklı özellikler gösteren bir ödünç sözleşmesi türüdür. Atletlerle yapılan tüketim ödüncü sözleşmeleri, olağan tüketim ödüncü sözleşmelerinden iki bakımdan farklılık göstermektedir. Ödünç alan profesyonel atletin katıldığı yarışmalarda zafer ve ödül kazanamadığı müddetçe aldığı ödüncü geri ödeme yükümlülügünün bulunmaması bu tip sözleşmeleri olağan tüketim ödüncü sözleşmelerinden ayıran önemli bir özelliktir. Atletlerle yapılan tüketim ödüncü sözleşmelerinde, tartışmalı olmakla birlikte, faiz için sözlü şekle bağlı stipulatio yerine şekle bağlı olmayan bir pactum (anlaşma) yapılmasının yeterli görülmüş olması, bu iki sözleşme arasındaki diğer bir farklılık olarak göze çarpmaktadır. Bu sözleşmenin taşıdığı özellikler göz önünde bulundurulduğunda, doktrinde farklı yönde görüşler olmasına rağmen, deniz ödüncü sözleşmesi ile benzerlikler gösterdiği söylenebilir. Tıpkı deniz ödüncü sözleşmesi gibi bu sözleşmede de antik Yunan etkisi görülmektedir.

Doktrinde atletlere verilen ödüncün neredeyse bağış gibi geri ödeme beklentisi olmaksızın ve geri ödenmesinin tamamen atletin inisiyatifine bırakılarak verildiğini ve geri ödeme için atlet zafer kazanmış olsa bile haklı bir sebep olmadıkça dava açılamayacağını savunan bir görüş bulunmakla birlikte, bu görüş inandırıcı delillerle desteklenememiştir. Aynı görüş uyarınca, atlete verilen ödünçte faiz talep edilmesinin de söz konusu olmadığı ve atletlere verilen ödünçlerle deniz ödünçleri arasında bir benzerlik olmadığı da savunulmaktadır. İlgili başlıklar altında ele aldığımız Digesta metinlerinde ise bu görüşün aksini ispatlayan ifadelerin yer aldığı görülmektedir. Atletlere yalnızca zafer kazandıklarında geri ödemeleri koşuluyla verilen ödünçlerle geri ödenmesi yalnızca geminin sâlimen limana varması koşuluna bağlanmış deniz ödünçleri arasında bir benzerlik olması kuvvetle muhtemeldir. Ayrıca bir atlete zafer kazandığında geri ödemesi koşuluyla verilen ödünç atlet tarafından zafer kazanılmış olmasına rağmen geri ödenmediğinde atlete karşı dava aç1labileceğini gösteren metinler mevcuttur. Keza, atletlere verilen ödünçler için sözlü şekle bağlı stipulatio yapılmadan yalnızca bir pactum (anlaşma) ile faiz talep edilebileceğini

${ }^{129}$ WACKE, s.448. 
açıç̧a ifade etmese bile bu doğrultuda yorumlanabilecek Digesta metni de, bu tip ödünçler için faizin söz konusu olabileceğini göstermektedir.

\section{KAYNAKÇA}

AKURGAL, Ekrem: "Eski Yunanlılarda Spor”, Eski Çağda Ege ve İzmir, İzmir, 1993, s.74-77 [Makalenin ilk basımı: Ülkü Dergisi, (17), 1943].

APAYDIN İSABABAYEVA, Ayna: "Antik Edebî ve Felsefi Kaynaklarda Aulos ve Syrin ve Tercüme Problemleri", Sosyal Bilimler Dergisi (SOBIDER), 2(2), 2015, s.53-72.

BEHRENDS, Okko/KNÜTEL, Rolf/KUPISCH, Berthold/SEILER, Hans Hermann: Corpus Iuris Civilis, Text und Übersertzung, auf der Grundlage der von Theodor Mommsen und Paul Krüger besorgten Textausgaben, Bd. II (1-10), C.F. Müller juristischer Verlag, Heidelberg, 1995; KNÜTEL/KUPISCH/SEILER/BEHRENDS, Bd. IV (21-27), Heidelberg, 2005.

BERTLING, Christoph/WASSONG, Stephan: "Striving for Athletic Excellence: A Core Value and Challange for the Profile of the Ancient and Modern Olympic Games", The International Journal of the History of Sport, 33(4), 2016, s.434-450, DOI: $10.1080 / 09523367.2016 .1143461$

(http://dx.doi.org/10.1080/09523367.2016.1143461) (Erişim tarihi: 08.09.2020).

BILLETER, Gustav: Geschichte des Zinsfusses im griechisch-römischen Altertum bis auf Justinian, Druck und Verlag von B. G. Teubner, Leipzig, 1898.

CORNELL, Tim J.: "On War and Games in the Ancient World", in Barney, Robert Knight/Martyn, Scott G./Wamsley, Kevin B. (ed.), Sixth International Symposium for Olympic Research 2002, University of Western Ontario, London, Ontario, 2002, s.29-40.

CRAIG, Steve: Sports and Games of the Ancients, Greenwood Publishing Group, Westport, 2002.

CROWTHER, Nigel B.: "Greek Games in Republican Rome" (Greek Games), L'antiquité classique, 52, 1983 , s.268-273.

CROWTHER, Nigel B.: "Second-Place Finishes and Lower in Greek Athletics" (Athletics), Zeitschrift für Papyrologie und Epigraphik, 90, 1992, s.97-102.

CROWTHER, Nigel B.: Sport in Ancient Times (Sport), Praeger, Westport, 2007.

ÇOKBANKİR ŞENGÜL, Nurşah: "Antikçağda Küçükasya'daki Sporcular: Sosyal Durumları, Profesyonellik ve Kentler", Cedrus, 1, 2013, s.151-162 (http://proje.akdeniz.edu.tr/mcri/cedrus/1-2013/cedrus-9-nursah_cokbankir_sengulantikcagda_kucuk_asyadaki_sporcular_sosyal_durumlari_profesyonellik_ve_kentler .pdf) (DOI: 10.13113/CEDRUS/20131683) (Erişim tarihi:08.09.2020).

DUNKLE, Roger: Gladiators: Violence and Spectacle in Ancient Rome (Gladiators), Routledge, London and New York, 2008.

FRIEDLAENDER, Ludwig: Darstellungen aus der Sittengeschichte Roms in der Zeit von August bis zum Ausgang der Antonine, Bd. II, 9. Aufl., Verlag von S.Hirzel, Leipzig, 1920.

GARDINER, Edward Norman: Athletics of the Ancient World, Ares Publishers, Inc., Chicago, 1983.

VON GLÜCK, Christian Friedrich: Ausführliche Erläuterung der Pandecten nach Hellfeld, Bd. 21, 1, Erlangen, Johann Jacob Palm, 1820.

GOLDEN, Mark: Sport in the Ancient World from A to Z (Sport), Routledge, London, 2004.

GREENIDGE, A.H.J.: Infamia, Its Place in Roman Public and Private Law, Clarendon Press, Oxford, 1894.

JAKAB, Éva: "Geld und Sport, Rezeption griechischer Topoi in der römischen Jurisprudenz", Revue Internationale de Droits de l'Antiquité (RIDA), 59, 2012, s.93-125.

KASER, Max: "Infamia und ignominia in den römischen Rechtsquellen." (Infamia), Zeitschrift der Savigny-Stiftung für Rechtsgeschichte, romanistische Abteilung, 73, 1956, s.220278.

KASER, Max: Das römische Privatrecht, das altrömische, das vorklassische und klassische Recht (RP I), erster Abschnitt, 2. Aufl., Verlag C. H. Beck, München, 1971.

KASER, Max: Das römische Privatrecht, die nachklassischen Entwicklungen (RP II), zweiter Abschnitt, 2. Aufl., Verlag C. H. Beck, München, 1975.

KYLE, Donald G.: "Greek Athletic Competitions-The Ancient Olympics and More" (Olympics), in Christesen, Paul/Kyle, Donald G. (ed.), A Companion to Sport and Spectacle in Greek and Roman Antiquity, WILEY Blackwell, Malden, 2014, s.21-35.

KYLE, Donald G.: Sport \& Spectacle in the Ancient World (Sport), Second Edition, WILEY Blackwell, Malden, 2015.

LEE, Hugh M.: "Greek Sports in Rome", in Christesen, Paul/Kyle, Donald G. (ed.), A Companion to Sport and Spectacle in Greek and Roman Antiquity, WILEY Blackwell, Malden, 2014, s.533-542.

LEONARD, Sugar Ray/ARKUSH, Michael: The Big Fight, My Life in and out of the Ring, Viking (Published by Penguin Group), New York, 2011. 
LITEWSKI, Wieslaw: “Römisches Seedarlehen”, Rivista Internazionale di diritto romano e antico (IURA), 24, 1973, s.112-183.

MANN, Christian: “Greek Sport and Roman Identity”, in Scanlon, Thomas F. (ed.), Sport in the Greek and Roman Worlds, Vol. 2: Greek athletic Identities and Roman Sports and Spectacle, Oxford University Press, Oxford, 2014, s.151-179.

MILLER, Stephen G.: Ancient Greek Athletics, Yale University Press, New Haven and London, 2004.

NEWBY, Zahra: Greek Athletics in the Roman World, Victory and Virtue, Oxford University Press, Oxford, 2005.

OTTO, Carl Eduard/SCHILLING, Bruno/SINTENIS, Carl Friedrich Ferdinand: Das Corpus Juris Civilis in's Deutsche Übersetzt von einem Vereine Rechtsgelehrter, Verlag von Carl Focke, Bd. I, 2. Aufl., Leipzig, 1839, Bd. II, Leipzig, 1831, Bd. IV, Leipzig, 1832, Bd. VI, Leipzig, 1832.

PLEKET, Henry Willy: "Zur Soziologie des antiken Sports" (Soziologie), Mededelingen van het Nederlands Instituut te Rome, 36, 1974, s.57-87 (http://resources.huygens.knaw.nl/retroboeken/knir/\#page=71\&accessor=toc1\&sour ce $=36 \&$ view=pdfPane) (Erişim tarihi: 08.09.2020).

PLEKET, Henry Willy: "The Olympic Games in antiquity” (Olympic Games), European Review, 12(3), 2004, s.401-413.

PLEKET, Henry Willy: "Inscriptions as Evidence in Greek Sport” (Inscriptions), in Christesen, Paul/Kyle, Donald G. (ed.), A Companion to Sport and Spectacle in Greek and Roman Antiquity, WILEY Blackwell, Malden, 2014, s.98- 111.

POTTER, David Stone: The Victor's Crown: A History of Ancient Sport from Homer to Byzantium, Oxford University Press, Oxford, 2012.

PRITCHARD, David M.: "Sport, War and Democracy in Classical Athens", The International Journal of the History of Sport, 26(2), 2009, s.212-245 (DOI: 10.1080/09523360802513272), (http://dx.doi.org/10.1080/09523360802513272) (Erişim tarihi: 08.09.2020).

RADO, Türkân: Roma Hukuku Dersleri, Borçlar Hukuku, İstanbul 2014.

REISCH, Emil: "Agones", (Agones), RE I, 1 (Paulys Realencyclopädie der classischen Altertumswissenschaft), Alfred Druckenmüller Verlag, Stuttgart, 1893.

REISCH, Emil: "Athletai" (Athletai), RE II, 2 (Paulys Realencyclopädie der classischen Altertumswissenschaft), Alfred Druckenmüller Verlag, Stuttgart, 1896.

REMIJSEN, Sofie: The End of Greek Athletics in Late Antiquity, Cambridge University Press, Cambridge, 2015.

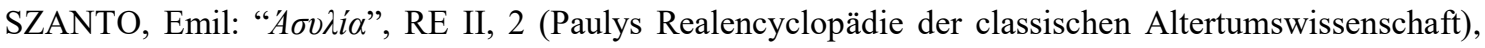
Alfred Druckenmüller Verlag, Stuttgart, 1896.

TEKİN, Oğuz: Eski Yunan ve Roma Tarihine Giriş, İletişim Yayınları, İstanbul, 2008.

TÜRKOĞLU ÖZDEMIR, Gökçe: Roma Hukukunda Infamia (Şerefsizlik), Seçkin Yayınları, Ankara, 2008.

UMUR, Ziya: Roma Hukuku Lügatı (Lügat), Fakülteler Matbaası, İstanbul, 1983.

UMUR, Ziya: Roma Hukuku, Tarihî Giriş- Kaynaklar-Umumî Mefhumlar-Hakların Himayesi (Roma Hukuku), Filiz Kitabevi, İstanbul, 1984.

WACKE, Andreas: Athleten als Darlehensnehmer nach römischem Recht, Studia et Documenta Historiae et Iuris (SDHI), 44, 1978, s.439-452.

WATSON, Alan: The Digest of Justinian, vol. I-II, University of Pennsylvania Press, Philadelphia, 1998.

WIEDEMANN, Thomas: Emperors and Gladiators, Routledge, London and New York, 1995.

YOUNG, David C.: A Brief History of the Olympic Games, Blackwell, Malden, 2004.

ZIMMERMANN, Reinhard: The Law of Obligations-Roman Foundations of the Civilian Tradition, Oxford University Press, Oxford, 1996.

Wikipedia-https://en.wikipedia.org/wiki/Winning_isn\%27t_everything;_it\%27s_the_only_thing (Erişim tarihi: 08.09.2020).

Türk Dil Kurumu: https://sozluk.gov.tr/?kelime=atlet (Erişim tarihi: 08.09.2020).

Türk Dil Kurumu: https://sozluk.gov.tr/?kelime=atletizm (Erişim tarihi: 08.09.2020). 